\title{
Occurrence, fate, and ecotoxicity of antibiotics in agro-ecosystems. A review
}

\author{
Lianfeng Du • Wenke Liu
}

Accepted: 14 October 2011 / Published online: 18 November 2011

(C) INRA and Springer-Verlag, France 2011

\begin{abstract}
Globally, besides human medicine, an increasing amount of antibiotics as veterinary drugs and feed additives are used annually in many countries with the rapid development of the breeding industry (livestock breeding and aquaculture). As a result, mostly ingested antibiotic doses $(30-90 \%)$ and their metabolites to humans and animals, as emerging persistent contaminants, were excreted together with urine and feces, and subsequently disseminated into environmental compartments in forms of urban wastewater, biosolids, and manures. More importantly, significant amount of antibiotics and their bioactive metabolites or degradation products were introduced in agro-ecosystems through fertilization and irrigation with antibiotics-polluted manures, biosolids, sewage sludge, sediments, and water. Subsequently, accumulation and transport of antibiotics in soil-crop systems, particularly soil-vegetable systems, e.g., protected vegetable and organic vegetable production systems, poses great risks on crops, soil ecosystem, and quality of groundwater- and plant-based products. The aim of this review is to explore the sources, fates (degradation, adsorption, runoff, leaching, and crop uptake), and ecological risks of antibiotics in agro-
\end{abstract}

\section{Du}

Institute of Plant Nutrition and Resources,

Beijing Academy of Agriculture and Forestry Sciences,

Beijing 100097, China

W. Liu $(\triangle)$

Institute of Environment and Sustainable Development in Agriculture, Chinese Academy of Agricultural Sciences, Beijing 100081, China

e-mail: liuwke@163.com

W. Liu

Key Lab. of Energy Conservation and Waste Management of Agricultural Structures, Ministry of Agriculture,

Beijing 100081, China ecosystems and possible food security and public health impacts. Three topics were discussed: (1) the occurrence, fates, and ecological impacts of antibiotics in agroecosystems, a global agro-ecological issue; (2) the potential ecological risks and public health threat of antibiotic pollution in soil-vegetable system, especially protected vegetable and organic vegetable production systems; and (3) the strategies of reducing the introduction, accumulation, and ecological risks of antibiotics in agro-ecosystems. To summarize, environmental contamination of antibiotics has become increasingly serious worldwide, which poses great risks in agro-ecosystems. Notably, protected vegetable and organic vegetable production systems, as public health closely related agro-ecosystems, are susceptible to antibiotic contamination. Occurrence, fate, and ecotoxicity of antibiotics in agro-ecosystems, therefore, have become most urgent issues among antibiotic environmental problems. Nowadays, source control, including reducing use and lowering environmental release through pretreatments of urban wastes and manures is a feasible way to alleviate negative impacts of antibiotics in agro-ecosystems.

Keywords Antibiotics · Ecological risks · Agro-ecosystem . Soil-vegetable system $\cdot$ Fate

\section{Contents}

1. Introduction. . . . . . . . . . . . . . . 2

2. Pathways of antibiotics entering agro-ecosystems. . 5

2.1 Fertilization with animal manures and urban wastes polluted by antibiotics. . . . . . . . .5 2.1.1 Concentrations of antibiotics in raw animal manures and urban biosolids. . . . . . . . . . .5 2.1.2 Antibiotic concentrations in treated animal manures and urban biosolids. . . . . . . . . . . .6 2.2 Irrigation with water polluted by antibiotics. . . .6 
3. Fates of antibiotic in agro-ecosystems. . . . . . . 7 3.1 Soil accumulation. . . . . . . . . . . . 8 3.2 Adsorption and degradation. . . . . . . . . 8 3.3 Leaching and runoff. . . . . . . . . . . . .9 3.4 Crop uptake. . . . . . . . . . . . . . . . . . .99

4. Effect of antibiotics in agro-ecosystems. . . . . . . . .9 4.1 Impacts on soil microorganisms and soil enzyme activity. . . . . . . . . . . . . . . . . . . . . . . . . . . . . . . 4.2 Phytotoxicity. . . . . . . . . . . . . . . 10

5. Risks related to antibiotics in agro-ecosystems, particularly PV-OVPS. . . . . . . . . . . . . 10 5.1 Use necessity, benefits and antibiotic risks of organic fertilizer in PV-OVPS. . . . . . . . . . . 10 5.2 Antibiotic pollution of agro-ecosystems, particularly PV-OVPS. . . . . . . . . . . . . . . . . 11

5.2.1 Soil, groundwater pollution. . . . . . . 11

5.2.2 Vegetable pollution by antibiotics. . . . . . 12

6. Research prospects. . . . . . . . . . . . . 12 6.1 Fates and ecological risks of antibiotics in agroecosystems: a global agro-ecological issue. . . . . . 12 6.2 Fates and ecological risks of antibiotics in PVOVPS: an urgent agro-ecological issue. . . . . . . 13 6.3 Strategies of lowering the introduction and ecological impacts of antibiotics in agro-ecosystems. . . . . . . . 13

6.3.1 Control the use of antibiotics as feed additives and human medicines to reduce excretion rate. . . .13 6.3.2 Developing pretreatment technology to decrease the quantity of antibiotics in organic fertilizer and irrigation water. . . . . . . 13 6.3.3 Clarifying fates and rhizosphere dynamics of antibiotics in agro-ecosystems. . . . . . . . 13

7. Concluding remarks. . . . . . . . . . . . . 14

\section{Introduction}

Broadly defined, antibiotics are organic substances that are produced through the secondary metabolism of living microorganisms or synthesized artificially or semiartificially that can kill other microorganisms or inhibit their growth or metabolic activity via biochemical actions (Lancini and Parenti 1982; Thomashow and Weller 1995; Thiele-Bruhn 2003). Mass production and use of antibiotics in medicine and agriculture have existed and substantially benefited public health and agricultural productivity for over 60 years (Knapp et al. 2010). Nowadays, a wide variety of antibiotics are extensively applied worldwide as drugs for preventing or treating human, animal, and plant infections, or as feed additives for animals and fishes to prevent or treat diseases as well as growth promotion (Cromwell et al. 1996; Smith et al. 2002; McManus et al. 2002; Kumar et al. 2005a, b; Sarmah et al. 2006; Cabello 2006; Aust et al. 2008; Stone et al. 2009). It was estimated that the total amounts of annual use of antibiotics had reached 100,000-200,000 tons worldwide (Wang and Tang 2010), including veterinary antibiotics and medical antibiotics. Among them, veterinary antibiotics are in the majority of the total amount used. For example, they approximately accounted for $70 \%$ of the total consumption in the USA and about $70 \%$ of them are used for nontherapeutic purposes (Sassman and Lee 2005; UCS 2001). Although the inclusion of antibiotics in feed for growth promotion in livestock production was banned in the European Union in 1998 (CEC 1998a, b) and Korea will cease the use of growth promotion antibiotics feed additives by 2012 (Kim et al. 2011), large-scale use of antibiotics in animal production is being widely adopted worldwide as drugs, particularly in the European Union, USA (Kolpin et al. 2002), China (Zhao et al. 2010), Southeast Asia, and Russia as feed additives or for prophylactic, metaphylactic, and therapeutic purposes (Hamscher et al. 2003; Sarmah et al. 2006). China is the largest country for production and use of antibiotics. In 2003, China produced 28,000 and 10,000 tons of penicillin and oxytetracycline (OTC), occupying $60 \%$ and $65 \%$ of the global total output (Yang et al. 2010a). On the other hand, antibiotics, as human medicines, have been extensively adopted in disease treatment globally, and their use frequency and dosage often surpass the actual need. Taking China for example, the proportion of antibiotics in drug prescription was over $70 \%$ in China, much higher than the proportion $30 \%$ in western countries, which reflected that the antibiotic misuse was more serious in China (Bruce et al. 2005).

With the rapid development of stockbreeding (e.g., livestock and poultry raising) and aquaculture (e.g., fishery), an unprecedented increment in used amount of veterinary antibiotics is undergoing. Among antibiotics, tetracyclines were the most commonly used, followed by sulfonamides and macrolides that accounted for approximately $90 \%$ of the total antibiotics used in the UK and more than 50\% in Korea and Denmark (Kim et al. 2011). Subsequently, about 30-90\% antibiotic doses to humans and animals, both unaltered and their metabolites, were excreted and released together with urine and feces after medication for incomplete absorption (Halling-Sørensen et al. 1998; Alcock et al. 1999; Winckler and Grafe 2001; Jjemba 2002a, b; Heberer 2002; Bound and Voulvoulis 2004; Phillips et al. 2004; Kumar et al. 2005b). Additionally, the amount rate of antibiotics excreted varies with the antibiotic species, the use dosage, as well as the type and the age of the animals (Katz 1980; Zhao et al. 2010). Furthermore, the overuse and abuse of antibiotics occur ubiquitous globally, which increases substantially the rates of excretion and environmental release (Smith et al. 2002). Some literatures showed that the excretion rates of some 
antibiotics, e.g., chlortetracycline (CTC), sulfamethazine (SMZ), and tylosin (TYL) after medication, exceeded 50\% (Montforts 1999; Winckler and Grafe 2001; EMEA 19942002; Arikan et al. 2009a, b). Most antibiotics come from various sources will eventually enter in environmental compartments through different pathways. It is apparent that the readily water-soluble ones are inclined to spread broadly and quickly with the aid of water fluidity. Therefore, taking the large environment-release quantity and antimicrobial attributes of antibiotics into consideration, the ecotoxic risks of antibiotics in environment, particularly agro-ecosystems would be the key environmental and human health concerns, and should be paid more scientific attentions on.

Three main pathways for environmental release of antibiotics are included, i.e., feed additives for stockbreeding and aquaculture, human and veterinary drugs, and environmental release during production or use (Fig. 1). Some antibiotics are bioactive and recalcitrant after excretion (Bouwman and Reus 1994; Dolliver et al. 2008). As human medicine, antibiotics were released into environment media in forms of wastewater and biosolids, and reached surface water and sediments via the release of effluents from sewage treatment plants (Hamscher et al. 2003; Giger et al. 2003; Göbel et al. 2004). All kinds of manures, as another important carrier of veterinary antibiotics, their transfer and seepage from manures to soil, surface, and groundwater also contribute the environmental release of antibiotics (Kim and Carlson 2005; Kim et al. 2005; Burkhardt et al. 2005; Kay et al. 2005). Moreover, water mobility will accelerate the environmental release and diffusion processes of some antibiotics, and consequently enlarged their geographic distribution and ecotoxicity in environmental compartments. Based on previous reports, environmental impacts of residual antibiotics include: (a) resistance evolution of pathogens and bacteria through long-time exposure, genetic variation, and transfer of antibiotic-resistant genes (ARGs), e.g., transferring resistance from nonpathogenic to pathogenic bacteria (Khachatourians 1998; Hirsch et al. 1999; Boxall et al. 2003); (b) human health impacts of antibiotic ingestion via animal- or plantbased food products and drinking water with antibiotic residues; (c) ecotoxic effects on nontarget organisms in aquatic environment and terrestrial environments, especially
Fig. 1 Sources, entrance pathways, fates of antibiotics in agroecosystems, and subsequent exposures to human

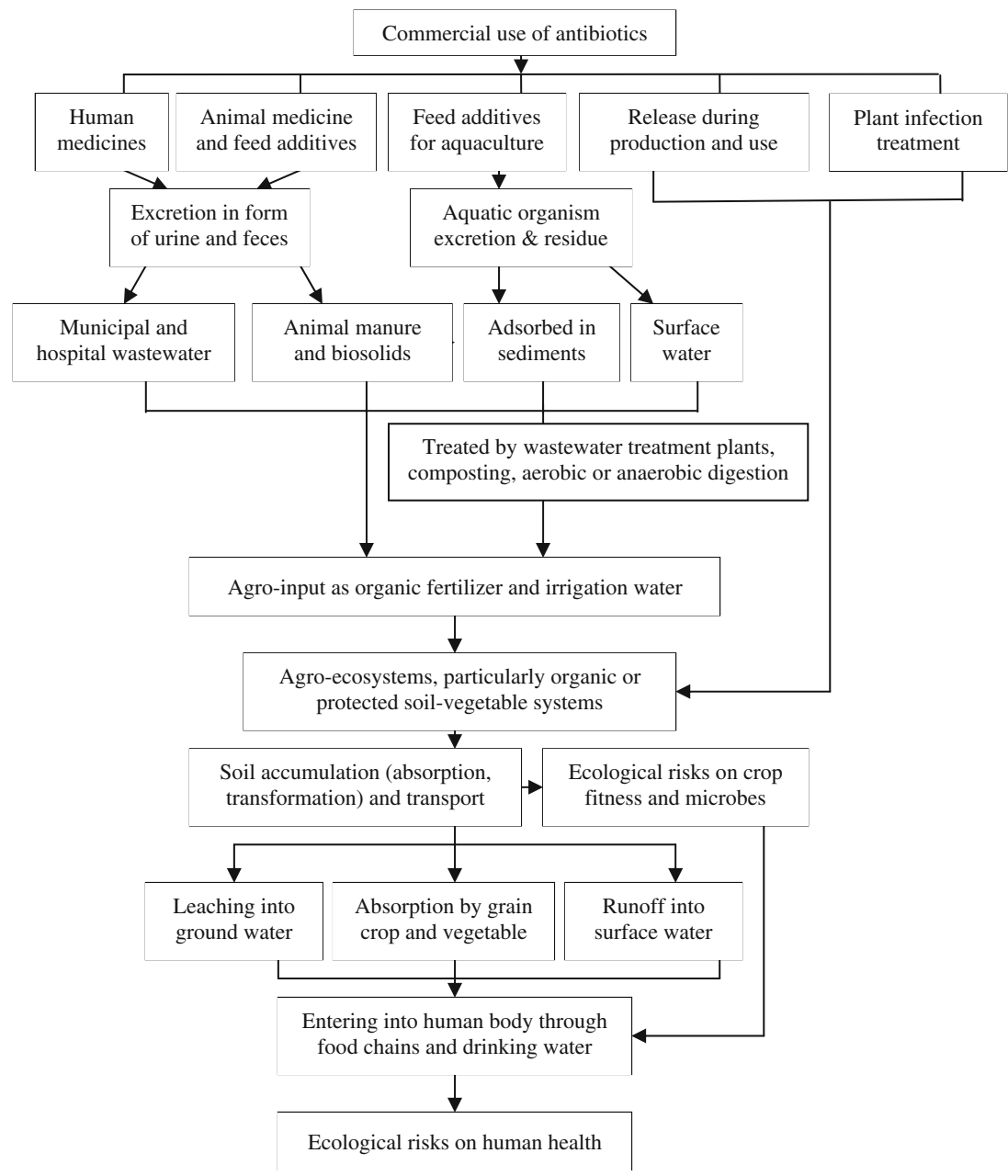


environmental microorganisms; and (d) ecological impacts on agro-ecosystems of introduced antibiotics through amending with manures (Wegener 1999; Kumar et al. 2005a; Boxall et al. 2006: Dolliver et al. 2007) and irrigated water. Recently, the occurrence of ARGs in various environmental components (sediments, soils, wastewater, and drinking water) has been detected, and their abundance in soils had increased significantly (Knapp et al. 2010). Thus, human being and animals are becoming subjected to a rising risk of superbug infection that cannot be treated with existing pharmacotherapy. To sum up, residual antibiotics in the environment may pose a serious threat to human health by antibiotic intake via food and drinking water, superbug infection, and so on.

Exposure and adverse effects of antibiotics to the water environment and terrestrial ecosystems have aroused great concern over the last decade. As a worldwide-growing concern issue, related studies dealing with occurrence, fate, and ecological risks of antibiotics have been conducted extensively, and the research data were updated and renewed quickly. There are more than 20 review articles on fates and ecological risks of antibiotics in Chinese (Zhang et al. 2005a, b, 2008a, b, c; Wang et al. 2006, 2007; Zhu and Song 2006; Kong and Zhu 2007; Zhou et al. 2007; Li et al. 2008; Wang and Tang 2010; Shi et al. 2010; Yang et al. 2010a; Wu et al. 2010a, b) and in English (HallingSørensen et al. 1998; Tolls 2001; Jjemba 2002a; Heberer 2002; Thiele-Bruhn 2003; Boxall et al. 2003; Kumar et al. 2005a; Sarmah et al. 2006; Kemper 2008; Snow et al. 2009; Ding and He 2010; Kim et al. 2011; Zhang and Li 2011) published in over the past decade. Many of them focused comments on the advances in exposure assessment in aquatic or terrestrial environment, fates (adsorption, translocation, and degradation), as well as ecological risks on ecosystems. However, few review literatures provided comprehensive summary that covered China and worldwide literatures and gave the overall and updated information on impacts of antibiotics in agro-ecosystem, particularly in protected vegetable and organic vegetable production systems (PV-OVPS).

Among agro-ecosystems, PV-OVPS are characterized by heavy application of organic fertilizer; therefore, they are much easier contaminated by antibiotics contained in manures, biosolids, and irrigation water. Organic fertilizer use as nutrient source and good soil amendment for PVOVPS; in turn, PV-OVPS are suitable places to utilize or recycle animal wastes with respect to the environmental and economic benefits. By the end of 2009, China's organic cultivation area has developed increasingly in the past decade, up to 1.85 million hectares, listing the third in the world (Willer and Lilcher 2010). In addition, the acreage of protected horticulture has sustainedly develop in the past decade, reaching 3.5 million square hectometers $\left(\mathrm{hm}^{2}\right)$ in
2009 (Liu et al. 2009b) in China, ranking first globally. More than $90 \%$ protected facilities are used for vegetable production, particularly off-season vegetables (Fig. 2). Therefore, massive organic manure is usually fertilized into PV-OVPS. Apparently, the fates and ecological risks of antibiotics introduced in protected systems may differ from that of in open fields due to the special environmental conditions in protected facilities and planting intensity. The beneficial roles of organic manure played in protected vegetable production, including (a) increasing $\mathrm{CO}_{2}$ emission and utilization by horticultural crops, (b) improving soil temperature to alleviate chilling stress, (c) providing nutrients, (d) ameliorating soil structure and avoiding succession cropping obstacle, and (e) alleviating soil secondary salinization caused by chemical fertilizer. Based on the above functions of organic manures, more and more organic manures were applied in protected agriculture. In some areas of China, it was estimated that the ratio of organic manure to total fertilizers used in protected facilities exceeded 60-87\% (Zhang et al. 2005a, b; Zhao and Chen 2001). In addition, the fertilization rate of organic manure reached $100-150$ tons $/ \mathrm{hm}^{2}$ (Xiao and Yang 1997; Zhao and Chen 2001). However, residual antibiotics and some other contaminants (e.g., heavy metals) in organic manure from scaled stockbreeding farms discounted the benefits brought by organic manures (Yao et al. 2006). As a result, antibiotics accumulation and vegetable contamination occurred increasingly. Moreover, many relevant studies, especially in China and Germany, published and deepened the understanding on this topic in recent years. More importantly, no document available has reviewed the occurrence, fates, and ecological risks of antibiotics in agro-ecosystems (Snow et al. 2009) with highlights on PVOVPS. Thus, collecting and summarizing the updated achievements in this field is helpful and necessary to impel future research. This review gives priority to the collection and comment on the novel documents issued after 2000 to supplement the existing review literatures.

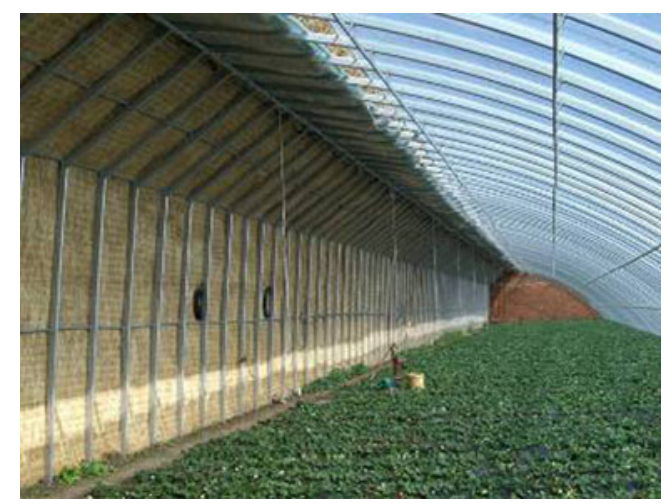

Fig. 2 Typical Chinese solar greenhouse for vegetable cultivation 


\section{Pathways of antibiotics entering agro-ecosystems}

Agro-ecosystems, such as croplands or vegetable fields, are the most important terrestrial environment where antibiotics-containing animal manures or organic wastes were applied largely and repeatedly. In summary, two avenues of antibiotics entering agro-ecosystems are involved: firstly, fertilization with antibiotics-containing animal manures, biosolids, sewage sludge, and sediments (Jørgensen and Halling-Sørensen 2000; Díaz-Cruz et al. 2003, 2006; Göbel et al. 2004; Kemper 2008; Yang et al. 2010b); secondly, irrigation with antibiotic-polluted reclaimed water from sewage treatment plants, wastewater, surface water, or groundwater (Renew and Huang 2004; Gulkowska et al. 2007) since they have been frequently polluted by antibiotics (Kolpin et al. 2002; Christian et al. 2003; Giger et al. 2003; Göbel et al. 2004; Renew and Huang 2004; Gulkowska et al. 2007; Fig. 1). Simultaneously, produce, e.g., vegetables and grains, cultivated in antibiotic-contaminated agro-ecosystems may pose the potential threat to public health when high-level antibiotics were absorbed and accumulated. Currently, application of manures to agro-ecosystems is a common practice in many countries in the world, including China, as periodic measure, especially for PV-OVPS. However, antibiotics have just aroused attention as potential pollutants in the past two decades (Halling-Sørensen et al. 1998; Kümmerer 2001a). Although some processes have been known about the exposure, fates, and risks of antibiotics in environmental compartments, very limited information pertaining to those processes in agro-ecosystems was revealed so far, particularly organic agriculture and protected agriculture. Therefore, monitoring, assessing, and controlling the pollution status of water and organic fertilizers are helpful for predicting or reducing the amounts of antibiotics into agro-ecosystems and their potential human health impacts (Fig. 1). Also, it is necessary to study and to comprehensively evaluate the fate of antibiotics in dairy farms, from administration to excretion, waste collection, land application, and potential soil-water transport (Watanabe et al. 2010). More importantly, since fertilization and irrigation is carried out repeatedly and frequently year-by-year, long-term monitoring on fates of antibiotics in agro-ecosystems should be systematically examined.

2.1 Fertilization with animal manures and urban biosolids polluted by antibiotics

Residual antibiotics in medicated animal manures and urban biosolids contribute as the major sources of antibiotics entered in agricultural soils via fertilization. Therefore, monitoring, evaluating, and controlling the residual level of antibiotics in animal manures are an important link for reducing their accumulation and deleterious impacts on agro-ecosystems. Generally speaking, antibiotic concentration in animal manure could be decreased significantly via composting and anaerobic fermentation treatment, which will favor the quantity reduction of antibiotic environmental exposure (Figs. 3 and 4). In order to evaluate the feasibility and efficiency of utilizing composting and anaerobic fermentation as control techniques to reduce environmental release of antibiotics, here the advances in treatment efficiency of composting and anaerobic fermentation on antibiotic removal from excretions were collected.

\subsubsection{Concentrations of antibiotics in raw animal manures and urban biosolids}

Many investigations have been conducted to examine the residual levels of antibiotics in animal dejecta and manures from large-scale livestock farms, mainly including slurry, dung, and manures of pig, cow, and chicken (Winckler and Grafe 2001; references in Table 1 and Kim et al. 2011). The residue levels for most antibiotics showed significant statistical differences among the sampling districts and the animal species (Zhao et al. 2010). Zhang et al. (2008a, b, c) showed that the residue level of selected antibiotics varied in sequence of pig manure $>$ chicken manure $>$ cow manure, and the antibiotics residues were generally higher in animal manures from industrial-scale farms than in those from farmer's households. Apart for animal excreta, residues of these substances in the farm dust present a new source of health hazard for farmers (Hamscher et al. 2003). Hamscher et al. (2003) detected up to five different antibiotics in $90 \%$ of dust samples collected during two decades from the same piggery. The total amounts were up to $12.5 \mathrm{mg} / \mathrm{kg}$ dust. The results suggested that dust from the farm is a route of entry for veterinary drugs in the environment and risks may arise from the inhalation of dust contaminated with antibiotics.

Urban biosolids are a source of antibiotic contamination for the agro-ecosystem because these substances are usually employed in agriculture. Biosolids refer to solid, semisolid, and liquid residues that are generated during the treatment of

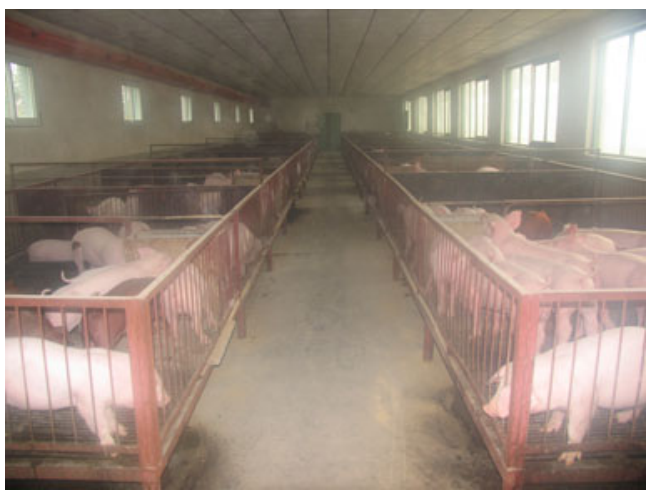

Fig. 3 Typical scaled livestock breeding in China 


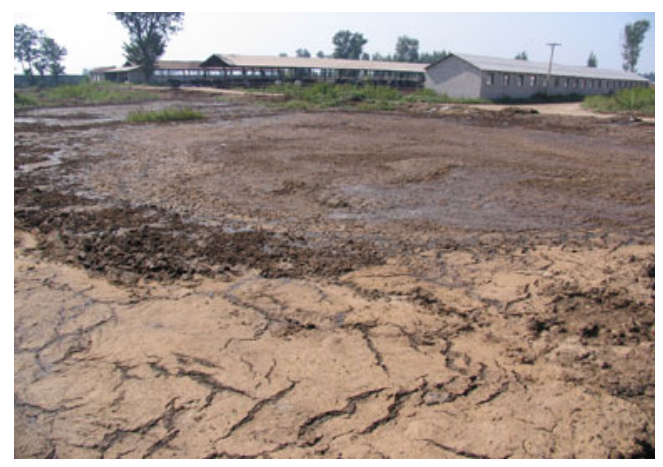

Fig. 4 Waste treatment of scaled livestock breeding

domestic sewage in treatment works. Antibiotic residues have been frequently detected in sewage, activated sludge, digested sludge, and urban biosolids (Zhang and Li 2011); the presence of antibiotics in these materials has become an increasingly recognized environmental risk as well (Halling-Sørensen et al. 1998; Hirsch et al. 1999; Jørgensen and Halling-Sørensen 2000). Some of the antibiotics can maintain residual activity in biosolids for a long time (Summer 2000). Zhang and $\mathrm{Li}$ (2011) summarized the latest information on occurrence, transformation, and fate of antibiotics in wastewater treatment plants based on more than 90 papers published.

\subsubsection{Antibiotic concentrations in treated animal manures and urban biosolids}

Whether or not there is pretreatment before environmental discharge or agricultural utilization determines the final residual concentrations of antibiotics in animal manures to some extent. Composting, anaerobic, and aerobic digestion

Table 1 The reports on antibiotic content in animal excreta

\begin{tabular}{|c|c|c|c|c|}
\hline Sites & Antibiotics species & $\begin{array}{l}\text { Sample } \\
\text { description }\end{array}$ & Average concentration & Reference \\
\hline Germany & TC, CTC & Liquid pig manure & $0.1-4 \mathrm{mg} / \mathrm{kg}$ & Hamscher et al. (2002) \\
\hline Germany & TYL, TC, SMZ, CAP & $\begin{array}{l}\text { 10-15 Dust samples } \\
\text { each year during } \\
\text { 1981-2000 from } \\
\text { piggery }\end{array}$ & $\begin{array}{l}\text { Detected in } 90 \% \text { samples, } \\
0.19-12.5\end{array}$ & Hamscher et al. (2003) \\
\hline $\begin{array}{l}\text { Seven provinces, } \\
\text { China }\end{array}$ & OTC, TC, CTC & $\begin{array}{l}32 \text { Pig and } 23 \text { chicken } \\
\text { manure samples }\end{array}$ & $\begin{array}{l}\text { Pig manure: } 9.09 \text { for OTC, } \\
5.22 \text { for TC, } 3.57 \text { for CTC; } \\
\text { chicken manure: } 5.97 \\
\text { for OTC, } 2.63 \text { for TC, } \\
1.39 \text { for CTC }\end{array}$ & Zhang et al. $(2005 a, b)$ \\
\hline Tianjin, China & $\begin{array}{l}\text { OTC, TC, CTC, } \\
\text { Doxycycline, SDZ, } \\
\text { SDM, SCP, SMZ, } \\
\text { SDO, Furazolidone, } \\
\text { CIP, Pefloxacin, CAP }\end{array}$ & $\begin{array}{l}9 \text { Pig manures and } \\
11 \text { chicken manures }\end{array}$ & $0.3-173 \mu \mathrm{g} / \mathrm{kg}$ & Hu et al. (2008) \\
\hline Zhejiang province, China & OTC, TC, CTC & $\begin{array}{l}93 \text { Pig, cow and } \\
\text { chicken manure samples }\end{array}$ & $\begin{array}{l}3.1 \text { for OTC, } 1.57 \text { for } \\
\text { TC, } 1.8 \text { for CTC }\end{array}$ & Zhang et al. (2008a, b, c) \\
\hline Jiangsu, China & $\begin{array}{l}\text { SG, SA, SD, SMR, SMD, } \\
\text { SMM, SCP, SMZ }\end{array}$ & 178 Manure samples & $0.08-7,105 \mu \mathrm{g} / \mathrm{kg}$ & Chen et al. (2008) \\
\hline Tianjin, China & $\begin{array}{l}\text { OTC, CIP, CTC, SMZ, } \\
\text { SDO, SCP, CAP, OFL, } \\
\text { PEF, CIP, LIN }\end{array}$ & $\begin{array}{l}\text { Winter manures and } \\
\text { summer manures }\end{array}$ & $\begin{array}{l}\text { Winter manures: 0.1-183.5; } \\
\text { summer manures: n.d.-29.3 }\end{array}$ & Hu et al. (2010) \\
\hline Eight provinces, China & FQ, SDM,TC & $\begin{array}{l}61 \text { Pig, } 54 \text { chicken } \\
\text { and } 28 \text { cow dung samples }\end{array}$ & $\begin{array}{l}\text { Pig and cow dung: up to } \\
34 \text { and } 30 \text { CIP, } 33 \text { and } 47 \\
\text { EFL, } 59 \text { and } 60 \text { OTC, } 21 \\
\text { and } 28 \text { CTC; chicken dung: } \\
\text { up to } 99 \text { fleroxacin, } 225 \\
\text { norfloxacin, } 46 \text { CIP, } \\
\text { 1,421 EFL }\end{array}$ & Zhao et al. (2010) \\
\hline
\end{tabular}

$A M X$ amoxicillin, $A O C$ aureomycin, $C A P$ chloramphenicol, $C T C$ chlortetracycline, $C I P$ ciprofloxacin, $E F L$ enrofloxacin, $F Q$ fluoroquinolones, LIN lincomycin, LSM lincosamides, OFL ofloxacin, OTC oxytetracycline, PEF pefloxacin, SMD sulfonamides, SMZ sulfamethazine, SMX sulfamethoxazole, $S D O$ sulfadoxine, $S C P$ sulfachloropyridazine, $S G$ sulfagidine, $S A$ sulfanilamide, $S D Z$ sulfadiazine, $S D M$ sulfadimidine, $S M M$ sulfamonomethoxine, SCP sulfachloropyridazine, SMR sulfamerazine, SMT sulfameter, SDM sulfadimethoxine, $T C$ tetracycline, $T Y L$ tylosin; $n . d$. not detected 
are well-established approaches for reducing the amount of antibiotics in animal manures (Kolz et al. 2005; Arikan et al. 2006, 2007, 2008; Stone et al. 2009; Mohring et al. 2009; Bao et al. 2009). The degradation rates of antibiotics during composting, anaerobic, or aerobic digestion varied with the species of antibiotic, the type of livestock manures, and the composting conditions. Moreover, removal technologies of antibiotics in sewage treatment plants were actively developed in the European Union and the USA (Kim et al. 2005; Castiglioni et al. 2006; Vieno et al. 2006; $\mathrm{Xu}$ et al. 2007a,b). A variety of commonly used antibiotics are persistent in the environment. Although some methods, including adsorption, biodegradation, disinfection, and membrane separation were developed to remove antibiotic in different wastewater treatment processes of municipal wastewater treatment plants, many antibiotics cannot be removed completely in wastewater treatment processes and would enter into environment via effluent and sludge (Ternes 1998; Zhang and Li 2011). On the other hand, antibiotics present may impact the efficiency of digestion and their degradation during treatment for their antimicrobial properties. Previous studies showed that antibiotics or metabolites in manure had negative effects on treatment systems such as anaerobic digesters (Poels et al. 1984) and nitrifying systems (Campos et al. 2001). However, Kakimoto et al. (2007) found that amoxicillin did significantly decrease the composting of human feces even at only $10 \mu \mathrm{g} / \mathrm{g}$ dry weight. In summary, source reduction through pretreatments is an effective method to control environmental release and contamination by antibiotics, but relevant techniques should be fully developed to enhance their efficiencies.

\subsection{Irrigation with water polluted by antibiotics}

Antibiotics could enter aquatic environment through urban sewerage systems and wastewater of livestock breeding (Fig. 5), and runoff and leaching from terrestrial ecosystems. Certainly, antibiotics in aquatic environment could be transported into agro-ecosystems via irrigation and sedi-

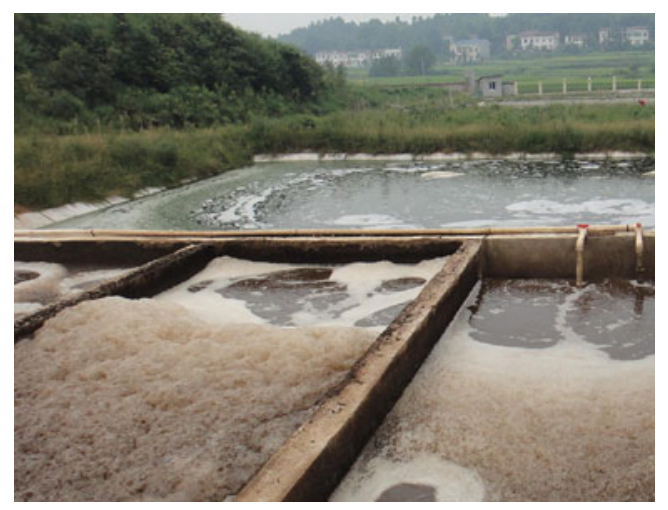

Fig. 5 Wastewater treatment of scaled livestock breeding ment utilization. As early as 1980s, high-level antibiotics detected in UK's river water in 1960s were reported (Watts et al. 1982). In addition, US survey revealed that a number of antibiotics were detectable in $27 \%$ of 139 rivers at concentrations of up to $0.7 \mu \mathrm{g} \cdot \mathrm{L}^{-1}$ (Kolpin et al. 2002). Up to now, antibiotics occurred widespread in surface waters (Lindsey et al. 2001; Christian et al. 2003; Managaki et al. 2007) and groundwaters (Sacher et al. 2001; Lindsey et al. 2001; Kolpin et al. 2002; Hamscher et al. 2005; Focazio et al. 2008), particularly the persistent, soluble species, e.g., CTC (Kolpin et al. 2002). CTC was found in $2.4 \%$ of the 84 surface water samples with the maximum concentration of $0.69 \mu \mathrm{g} / \mathrm{L}$ by Kolpin et al. (2002). Many reports had detected antibiotic pollution in water bodies in Asia (Xu et al. 2007a, b; Gulkowska et al. 2007) and Europe (Golet et al. 2002; Christian et al. 2003; Stolker et al. 2004; Lindberg et al. 2005; Tamtam et al. 2008), particularly for water from sewage treatment plants (Alcock et al. 1999; Lindberg et al. 2005; Castiglioni et al. 2006; Vieno et al. 2006; Xu et al. 2007a, b; Pedrouzo et al. 2011). Giger et al. (2003) detected antibiotics in hospital and municipal wastewater. Gulkowska et al. (2007) detected tetracycline (TC), erythromycin, norfloxacin, and trimethoprim in Hong Kong coastal waters. Managaki et al. (2007) reported that the veterinary antibiotics, e.g., erythromycin, trimethoprim, and various sulfonamides, were detected in the Mekong Delta in Vietnam. Additionally, the highest concentrations in both water and sediment samples occurred in winter and sediment samples had greater detection frequencies and higher concentrations than water samples (Kim and Carlson 2007). This might be attributed to the seasonal changes of antibiotic concentrations from sewage treatment plants and hospitals (Pena et al. 2010). In view of the frequent occurrence and accumulation of antibiotics in natural water in global areas; thereafter, the species and rate of antibiotics entering agro-ecosystems by irrigation may tend to increase.

\section{Fates of antibiotics in agro-ecosystems}

Agro-ecosystems are the ideal places to employ and utilize animal manures. However, high anthropogenic input quantity and low harmless treatment rate of animal manures unavoidably result in continuous accumulation of antibiotics in agro-ecosystems through repeated fertilization. Taking China as an example, annual production of animal wastes in China had climbed up to 2-3 billion tons and only $50 \%$ was utilized. More importantly, the harmless treatment rate of animal wastes is just about $11 \%$ (Zhang 2008). After entering agricultural soil of antibiotics, several interrelated processes were involved, including degradation (Kreuzig and Höltge 2005), adsorption (Rabølle and Spliid 2000), transport (leaching and runoff) (Blackwell et al. 
2007), and plant uptake (Migliore et al. 1996; Kumar et al. 2005a; Boxall et al. 2006; Dolliver et al. 2007). The active ingredients in the upper soil layer might either accumulate in soil or be absorbed by crops, or be readily available for transport into surface and groundwater through leaching and overland flow runoff (Jongbloed and Lenis 1998). All dynamic processes of antibiotics in soils are closely interrelated and driven by crop, soil microorganism, water, and anthropogenic activities, which will ultimately determine the spatial-temporal distribution and environmental impacts of antibiotics.

\subsection{Soil accumulation}

Soil is a habitat of indigenous antibiotics produced by soil microorganisms (Gottlieb 1976; Thomashow et al. 1997). Topp (1981) found that less half-soil actinomycetes isolated were able to synthesize antibiotics, also in in situ rhizosphere, the background level of antibiotics was up to $5 \mu \mathrm{g} / \mathrm{g}$ soil (Lumsden et al. 1992; Shanahan et al. 1992). Some exogenous antibiotics incorporated soil through fertilization and irrigation were persistent and cumulative, which resulted in an increasingly residual concentrations ranged from a few micrograms up to grams per kilograms (see Table 2; Thiele-Bruhn 2003). Many countries had detected the antibiotic residues in soils (Boxall 2004; Hamscher et al. 2005; Martinez-Carballo et al. 2007). As previously reported, TC could persist in soil for over 1 year (Zuccato et al. 2000), and only a moderate degradation of various TCs occurred within 180 days (Hamscher et al. 2002). Hamscher et al. (2002) detected the concentration of $\mathrm{TC}$ up to $0.3 \mathrm{~g} / \mathrm{kg}$ in farmland soil fertilized with liquid manure. Also, $9.5 \mu \mathrm{g} / \mathrm{kg}$ CTC in the upper $10 \mathrm{~cm}$ soil from eight fields manured with animal slurry 2 days before sampling were detected (Kolpin et al. 2002). Zhang et al. (2008a, b, c) found that about $93 \%, 88 \%$, and $93 \%$ of surface soils $(0-20 \mathrm{~cm})$ applied manure contained OTC, $\mathrm{TC}$, and $\mathrm{CTC}$, and their soil residues were 38,13 , and 12 times as high as those soils without manure application. Martinez-Carballo et al. (2007) detected CTC, enrofloxacin, and ciprofloxacin in arable Austrian soils. In addition, halflives of some antibiotics in soils were examined (Schlüsener and Bester 2006; Accinelli et al. 2007).

\subsection{Adsorption and degradation}

Soil adsorption is the main physicochemical mechanism that prevents the antibiotics from leaching or runoff to some extent.

Table 2 Antibiotics concentration in soils

\begin{tabular}{|c|c|c|c|c|}
\hline Site & Antibiotics species & Concentration detected & Sample description & Reference \\
\hline Germany & $\mathrm{CTC}, \mathrm{TC}$ & $\begin{array}{c}86.2,198.7,171.7 \mathrm{mg} / \mathrm{kg} \\
\mathrm{TC} ; 4.6-7.3 \mathrm{mg} / \mathrm{kg} \mathrm{CTC}\end{array}$ & $\begin{array}{r}0-10,10-20 \text { and } \\
20-30 \mathrm{~cm} \text { soils }\end{array}$ & Hamscher et al. (2002) \\
\hline Zhejiang, China & OTC, CTC & $\begin{array}{l}\text { OTC, } 0.44-1.23 ; \text { CTC, } \\
0.44-1.56 \mathrm{mg} / \mathrm{kg}\end{array}$ & 0-20 cm soil & Wang and Han (2008) \\
\hline $\begin{array}{l}\text { Zhejiang province, } \\
\text { China }\end{array}$ & OTC, TC, CTC & $\begin{array}{l}0.64 \text { for OTC, } 0.65 \text { for } \\
\text { TC; } 0.56 \text { for CTC } \mathrm{mg} / \mathrm{kg}\end{array}$ & $\begin{array}{l}48 \text { Surface } 0-20 \mathrm{~cm} \\
\text { and subsurface } \\
20-40 \mathrm{~cm} \text { soils }\end{array}$ & Zhang et al. (2008a, b, c) \\
\hline Guangdong, China & $\begin{array}{l}\text { OTC, TC, CTC, SDZ, } \\
\text { SMR, SMT, SMZ,SDM }\end{array}$ & n.d. $-321.6 \mu \mathrm{g} / \mathrm{kg}$ & $\begin{array}{l}31 \text { Surface soils } \\
(0-30 \mathrm{~cm}) \\
\text { of vegetable fields }\end{array}$ & Li et al. (2009b) \\
\hline Guangdong, China & NOR, CIP, LOM, EFL & $\begin{array}{l}\text { Surface soils } 3.97-32.03 \mu \mathrm{g} / \mathrm{kg} \\
19.5-23 \mu \mathrm{g} / \mathrm{kg} \text { for } 0-20 \mathrm{~cm} \\
2.5-12 \mu \mathrm{g} / \mathrm{kg} \text { for } 20-40 \mathrm{~cm} \\
2.4-5 \mu \mathrm{g} / \mathrm{kg} \text { for } 40-60 \mathrm{~cm} \\
\text { n.d. }-2.2 \mu \mathrm{g} / \mathrm{kg} \text { for } 60-80 \mathrm{~cm}\end{array}$ & $\begin{array}{l}\text { Surface soils } 0-20 \mathrm{~cm} \text {; } \\
\text { vegetable field } 0-20 \\
20-40,40-60 \\
60-80 \mathrm{~cm} \text { soils }\end{array}$ & Tai et al. (2010) \\
\hline Tianjin, China & $\begin{array}{l}\text { OTC, TC, CTC, SMZ, } \\
\text { SDO, SCP, CAP, OFL, } \\
\text { PEF, CIP, LIN }\end{array}$ & $\begin{array}{l}\text { Winter soils: n.d. }-2.68 \text {; summer } \\
\text { soils: n.d. }-2.5 \mu \mathrm{g} / \mathrm{kg}\end{array}$ & Winter soils, summer soils & Hu et al. (2010) \\
\hline Guangdong, China & TCs, SMDs, quinolones & $242.6,33.3-321.4,27.8-1,537.4 \mu \mathrm{g} / \mathrm{kg}$ & Vegetable field soils & Li et al. (2011) \\
\hline
\end{tabular}

$C A P$ chloramphenicol, $C T C$ chlortetracycline, CIP ciprofloxacin, EFL enrofloxacin, $L I N$ lincomycin, $L O M$ lomefloxacin, NOR norfloxacin, $O F L$ ofloxacin, $O T C$ oxytetracycline, $P E F$ pefloxacin, $S M D$ sulfonamides, $S M Z$ sulfamethazine, $S D O$ sulfadoxine, $S C P$ sulfachloropyridazine, $S D Z$ sulfadiazine, SMR sulfamerazine, SMT sulfameter, SDM sulfadimethoxine, TC tetracycline, n.d. not detected 
The extent of antibiotic adsorption to soils depends on the antibiotic species present and soil properties including $\mathrm{pH}$, organic matter content, and the concentration and type of divalent cations present, regardless of soil type (Rabølle and Spliid 2000). Dissolved organic matter decreased sorption of antibiotics to clay by increasing their mobility (Kulshrestha et al. 2004). Sorption to sterile manure, compost, and humic acid was determined to be strongly affected by contact time and pH. Kurwadkar et al. (2007) also found a strong pH dependency for sorption of sulfathiazole and SMZ to three sand and loam soils. TCs are known to bind strongly to soil particles, due to their ability to form complexes with doubly charged cations (e.g., $\mathrm{Ca}^{2+}$; Tolls 2001; Hamscher et al. 2002). Sassman et al. (2007) also studied sorption and degradation of TYL and its degradation products. Residues of OTC, TC, and CTC correlated positively to soil clay content. The more porous the soil texture, the more antibiotics are liable to transport and accumulate in the subsurface horizons of many soils (Zhang et al. 2008a, b, c). Soil-contained antibiotics may degrade completely or partially of the parental compound (Kümmerer 2001b) through three degradation behaviors (Schlüsener and Bester 2006) driven by biodegradation and photodegradation. The photodegradability of antibiotics in aqueous and soil environments is an important factor in environmental fate. Thiele-Bruhn and Peters (2007) observed significant photodegradation of various TC and sulfonamides in sterile water and soil surfaces.

\subsection{Leaching and runoff}

Mobility and transport of accumulated antibiotics are important processes involved in environmental issue, which may evoke when irrigation and precipitation occur. Leaching of antibiotics into deeper soil or into groundwater depended on the adsorption strength of the drugs in topsoil (Hamscher et al. 2002). Stoob et al. (2007) conducted a field study of sulfonamide runoff from cropland to surface water. Results suggested a worst-case scenario of $0.5 \%$ runoff loss for sulfonamides. Wehrhan et al. (2007) reported extensive column studies of SDZ leaching. Kay et al. (2005) examined the antibiotics concentrations in the overland flow in an irrigated arable land after 4-h pig slurry application. They found that sulphachloropyridazine and OTC was detectable in runoff from the tramline plot at a peak concentration of 0.7 and $0.072 \mathrm{mg} / \mathrm{L}$. However, TYL was not detected. Blackwell et al. (2007) determined OTC fate in soil and very low concentrations were detected in surface runoff but not in soil pore water.

\subsection{Crop uptake}

High-level accumulation of antibiotics in food crops may raise potential human health concerns through food chain. Previous studies showed that crops could absorb from antibiotics-polluted soils or manure-amended soils (Table 3 ).

Table 3 Antibiotic concentration in crops

\begin{tabular}{|c|c|c|c|c|}
\hline Site & Crop species & Antibiotics species & Concentration detected & Reference \\
\hline Italy & Millet, pea, corn and barley & SMZ & $\begin{array}{l}1,000-2,000 \mu \mathrm{g} / \mathrm{kg} \text { in } \\
\text { foliage and root }\end{array}$ & Migliore et al. (1996) \\
\hline Italy & $\begin{array}{l}\text { Weed species: Amaranthus } \\
\text { retroflexus L., Plantago } \\
\text { major L., Rumex acetosella L. }\end{array}$ & SDM & $981-6,065 \mu \mathrm{g} / \mathrm{kg}$ & Migliore et al. (1997) \\
\hline USA & Corn & SMZ & $<1.06 \mathrm{mg} / \mathrm{kg}$ & Kumar et al. (2005a) \\
\hline China & Alfalfa (Medicago sativa L.) & OTC & $\begin{array}{l}\text { OTC absorbed by alfalfa, } \\
\text { and the uptake inhibited } \\
\text { by } 2,4 \text {-dinitrophenol and } \mathrm{Hg}^{2+}\end{array}$ & Kong et al. (2007) \\
\hline USA & Corn & SMZ & $0.9-1.2 \mathrm{mg} / \mathrm{kg}$ & Dolliver et al. (2007) \\
\hline USA & Wheat & CTC, SDZ & $\begin{array}{l}\text { Root } 1.1 \text { and } 0.5 \text { for CTC and } \\
\text { SDZ; } 0.043 \text { of CTC was } \\
\text { detected in wheat grain }\end{array}$ & Grote et al. (2007) \\
\hline USA & Soybean & $\begin{array}{l}\text { Carbamazepine, } \\
\text { diphenhydramine, } \\
\text { fluoxetine }\end{array}$ & $\begin{array}{l}\text { Carbamazepine, triclosan } \\
\text { accumulated in root tissues } \\
\text { and above ground parts; } \\
\text { diphenhydramine and fluoxetine }\end{array}$ & Wu et al. $(2010 a, b)$ \\
\hline
\end{tabular}

$C T C$ chlortetracycline, $O T C$ oxytetracycline, $S M D$ sulfonamides, $S M Z$ sulfamethazine, $S D Z$ sulfadiazine 
Generally, the uptake and effects on plants varies considerably between reports and depends on the antibiotic and plant species (Migliore et al. 1995; Kumar et al. 2005a; Dolliver et al. 2007). Some antibiotics, e.g., TYL, could not be absorbed by corn, green onion, and cabbage (Kumar et al. 2005a) because of their large molecular weight. Although the maximum residue value for antibiotics in animal-based products has been established, the limit for antibiotics in plant-based products is absent yet (JECFA 2006).

\section{Effects of antibiotics in agro-ecosystems}

Nowadays, antibiotics are being considered as ubiquitously occurring persistent contaminants in agro-ecosystems, and their ecological risks are a growing problem with respect to agro-environmental quality. Many antibiotics are persistent with long half-lives in soils. Long-term accumulation of persistent antibiotics and their metabolites in agro-ecosystems are bioactive and ecotoxic to soil microorganisms and crops, particularly bacteria (Baguer et al. 2000). Here, we summarized the research advances in ecotoxicity of antibiotics in agro-ecosystems, including soil microorganisms, soil enzyme activity, and crops.

\subsection{Impacts on soil microorganisms and soil enzyme activity}

Environmental antibiotics are still bioactive chemicals that are potentially hazardous to soil bacteria and other organisms (Baguer et al. 2000). The side effects of antibiotics on nontarget soil organisms are the issues of most concern in ecological risks assessment since they are highly effective and bioactive substances. A number of soil microbiological parameters, including microbial biomass and basal respiration, have been suggested as possible indicators of soil environmental monitoring programs (Yao et al. 2000; Winding et al. 2005). Degraded products of antibiotics also exhibited toxicity to microorganisms (Ge et al. 2010). In general, residual antibiotics in the soils may possibly assist in developing antibiotic resistant microbial populations (Witte 1998; Morris and Masterton 2002), microbial activity (Jjemba 2002a, b), and alter soil microbial constitution and functions. The occurrence of ARGs in various soil bacteria has been detected and their abundance in soils had increased significantly (Knapp et al. 2010). Generally speaking, there is limited information available on the direct effects of these drugs on soil biota, particularly those living in rhizosphere. Furthermore, previous reports on the effects of pharmaceutical antibiotics on soil microorganisms are inconsistent (Thiele-Bruhn and Beck 2005; Kong et al. 2006; Zielezny et al. 2006; Kotzerke et al. 2008). Ding and He (2010) summarized the effect of antibiotics in the environment on microbial populations.

Diao et al. (2004) reported that apramycin inhibited soil bacteria growth significantly. Previous studies showed that oxidative stress induced by fenpropimorph and fenhexamid could be alleviated by arbuscular mycorrhiza (Campagnac et al. 2010), and arbuscular mycorrhiza benefited for the detoxification of xenobitics, a pharmaceutical paracetamol (Khalvati et al. 2010). However, the impacts of antibiotics on formation and function arbuscular mycorrhizal symbiosis were little investigated up to now. Kotzerke et al. (2011) investigated the effects of manure containing different concentrations of the antibiotic amoxicillin on microbial community function in soils over an incubation time of 18 days. Soil potential nitrification rate was not significantly affected. Currently, there is lack of the understanding on ecotoxic impacts of antibiotics on soil ecology, particularly growth, community structure, function, and diversity. In addition, some beneficial rhizosphere microorganisms, like arbuscular mycorrhizal fungus and rhizobium have not been investigated yet till now.

The impacts on soil organisms of antibiotics will certainly modify enzyme activities and soil biochemical processes. Wei et al. (2009) showed that the presence of TC significantly disturbed the structure of microbial communities and inhibited soil microbial activities in terms of urease, acid phosphatase, and dehydrogenase. The antibiotics, including CTC, TC, TYL, SMX, SMZ, and trimethoprim, inhibited soil phosphatase activity during the 22 days' incubation. Significant effects on soil respiration were found for the two sulfonamides (SMX and SMZ) and trimethoprim, whereas little effects were observed for the two TC and TYL (Liu et al. 2009a). OTC decreased the urease, sucrase, phosphatase, hydrogen peroxidase, and microbial biomass nitrogen in rhizosphere of wheat, and increased the microbial biomass carbon (Yao et al. 2010).

\subsection{Phytotoxicity}

Phytotoxicity of antibiotics had been examined through seed germination experiment (Liu et al. 2009a, b) and plant growth tests (Wei et al. 2009), varying between plant species and antibiotic compounds (Batchelder 1982; Jjemba 2002a; Farkas et al. 2007; Liu et al. 2009a, b; see Table 4). The earlier results dealing with the effects of antibiotics on plants were reviewed by Jjemba (2002b) and Thiele-Bruhn (2003). Three hundred milligram per liter sulphadimethoxine (SDM) in agar and soil-based laboratory systems significantly reduced root, stalk, and leaf growths of millet, pea, corn, and barley (Migliore et al. 1996). These authors identified bioaccumulation as the mechanism causing the 
Table 4 Phytotoxicity of antibiotics

\begin{tabular}{|c|c|c|c|c|}
\hline Sites & Plant species & Antibiotics species & $\begin{array}{l}\text { Impacts or concentration } \\
\text { detected }\end{array}$ & Reference \\
\hline Italy & $\begin{array}{l}\text { Cucumis sativus L., Lactuca } \\
\text { sativa L., Phaseolus vulgaris } \\
\text { L., Raphanus sativus L. }\end{array}$ & EFL & $\begin{array}{l}\text { Modifying the length of } \\
\text { primary root, hypocotyl, } \\
\text { cotyledons and the } \\
\text { number/length of leaves }\end{array}$ & Luciana et al. (2003) \\
\hline Beijing, China & Alfalfa & OTC & $\begin{array}{l}\text { Inhibiting growth of stem } \\
\text { and root }\end{array}$ & Kong et al. (2007) \\
\hline China & Wheat & OTC, TC & $\begin{array}{l}\text { Inhibiting root and shoot } \\
\text { elongation }\end{array}$ & Bao et al. (2008) \\
\hline Liaoning, China & Lettuce & OTC & Growth were inhibited & Cui et al. (2008) \\
\hline Guangdong, China & $\begin{array}{l}\text { Sweet oat, rice } \\
\text { and cucumber }\end{array}$ & $\begin{array}{l}\text { CTC, TC, TLY, SMZ, } \\
\text { trimethoprim }\end{array}$ & Germination inhibited & Liu et al. (2009a) \\
\hline Henan, China & $\begin{array}{l}\text { Chinese cabbage } \\
\text { and tomato }\end{array}$ & SDZ, SDM, EFL & $\begin{array}{l}\text { Inhibitory effects on root } \\
\text { elongation and shoot } \\
\text { elongation }\end{array}$ & Jin et al. (2009) \\
\hline Hongkong, China & Ryegrass & $\mathrm{TC}$ & $\begin{array}{l}\text { Plant biomass, especially } \\
\text { the roots reduced; Plant } \\
\mathrm{P} \text { assimilation decreased }\end{array}$ & Wei et al. (2009) \\
\hline Beijing, China & 63 wheat species & OTC & $\begin{array}{l}\text { Biomass and chlorophyll } \\
\text { in leaves decreased }\end{array}$ & Xie et al. (2009) \\
\hline
\end{tabular}

$C T C$ chlortetracycline, EFL enrofloxacin, $O T C$ oxytetracycline, $S M Z$ sulfamethazine, $S D Z$ sulfadiazine, $S D M$ sulfadimidine, $T C$ tetracycline, $T Y L$ tylosin

phytotoxic response since concentrations as high as 1,000 and $2,000 \mathrm{mg} / \mathrm{kg}$ SDM were reported in the foliage and root materials, respectively (Migliore et al. 1996). Kong et al. (2007) found that $0.002-0.2 \mathrm{mM}$ OTC significantly inhibited the growth of alfalfa at $61-85 \%$ and they suggested that OTC uptake into alfalfa is an energydependent process. Currently, limited studies have been conducted to investigate the phytotoxicity of antibiotics to crop plants (Migliore et al. 1998, 2003; Kong et al. 2007). When grown in CTC-treated soil, a significant increase in the activities of the plant stress proteins glutathione Stransferases and peroxidases was observed in maize plants, but not in pinto beans (Farkas et al. 2007). Boxall et al. (2006) found that carrot and lettuce growth were inhibited by spiking at a concentration of $1 \mathrm{mg}$ antibiotic per kilogram soil. Genotypic differences in responses of wheat to OTC were found among 63 wheat cultivars tested. The most sensitive cultivar to OTC with the EC50 value of $1.25 \mathrm{mg} / \mathrm{L}$, and the most insensitive cultivar to OTC with the EC50 value of $54.21 \mathrm{mg} / \mathrm{L}$, and chlorophyll contents in leaves of the two wheat cultivars tested decreased with the increase of OTC concentrations (Xie et al. 2009).

\section{Risks related to antibiotics in soil-vegetable systems, particularly PV-OVPS}

5.1 Use necessity, benefits, and antibiotic risks of organic fertilizer in PV-OVPS

Recently, the environmental fates and impacts of antibiotics as emerging pollutants in PV-OVPS have been paid growing attention on (Shi et al. 2010; Hu et al. 2010). In order to balance nutrients and to overcome continuous cropping obstacle dysfunctions, vegetable production in PV-OVPS needs to apply more organic manures than other agro-ecosystems. More importantly, organic fertilizer as the principal nutrient source and soil amendments for PV-OVPS is supplied repeatedly and annually in large scales. Consequently, antibiotics were introduced PV-OVPS together with organic fertilizer in large quantity and possibly accumulated up to a high level both in soil, groundwater, and vegetables. Currently, this is unavoidable since the majority of organic fertilizer could only originate from large-scaled livestock farms where antibiotics were intensively used. Antibiotic con- 
Table 5 Antibiotics absorption and accumulation of vegetables

\begin{tabular}{|c|c|c|c|c|}
\hline Sites & Plant species & Antibiotics species & Concentration detected & Reference \\
\hline Minnesota, USA & Green onion, cabbage & CTC,TYL & $\begin{array}{l}0.002-0.017 \mathrm{mg} / \mathrm{kg}, \mathrm{CTC} \\
\text { TYL not detected }\end{array}$ & Kumar et al. (2005a) \\
\hline Minnesota, USA & Carrot, lettuce & $\begin{array}{l}\text { EFL, florfenicol, levamisole, } \\
\text { trimethoprim }\end{array}$ & $\begin{array}{l}\text { lettuce leaves, } 6-170 \\
\mu \mathrm{g} / \mathrm{kg} ; \text { carrot root } \\
2.8-13 \mu \mathrm{g} / \mathrm{kg}\end{array}$ & Boxall et al. (2006) \\
\hline Minnesota, USA & Lettuce, potato & SMZ & $0.1-1.2 \mathrm{mg} / \mathrm{kg}$ & Dolliver et al. (2007) \\
\hline Zhejiang, China & $\begin{array}{l}\text { Leek, celery, pakchoi } \\
\text { cabbage and radish }\end{array}$ & OTC, CTC & $\begin{array}{l}\text { Leek root, OTC } \\
0.0277-0.0364 ; \\
\text { CTC } 0.139 \mathrm{mg} / \mathrm{kg}\end{array}$ & Wang and Han (2008) \\
\hline Guangdong, China & $\begin{array}{l}\text { Green pepper, potato, } \\
\text { sweet potato, ipomoea } \\
\text { aquatica, Chinese } \\
\text { flowering cabbage, } \\
\text { lettuce, carrot, bitter } \\
\text { melon, white gourd }\end{array}$ & $\begin{array}{l}\text { Sulfathiazole, sulfapyridine, } \\
\text { SDZ, SMD, SMT, SMZ }\end{array}$ & $0.38-2.24 \mathrm{mg} / \mathrm{kg}$ & Bao et al. (2010) \\
\hline Guangdong, China & $\begin{array}{l}\text { Green pepper, potato, } \\
\text { sweet potato, ipomoea } \\
\text { aquatica, Chinese } \\
\text { flowering cabbage, } \\
\text { lettuce, carrot, bitter } \\
\text { melon, white gourd }\end{array}$ & OTC, TC & $\begin{array}{c}\text { OTC, TC ranged from } \\
0.041-0.174 \text { and } \\
0-0.048 \mathrm{mg} / \mathrm{kg}\end{array}$ & Yao et al. (2010) \\
\hline Tianjin, China & $\begin{array}{l}\text { Radish, rape, celery } \\
\text { and coriander }\end{array}$ & $\begin{array}{l}\text { OTC, TC, CTC, SMZ, } \\
\text { SDO, SCP, CAP, OFL, } \\
\text { PEF, CIP, LIN }\end{array}$ & $0.1-532 \mu \mathrm{g} / \mathrm{kg}$ & Hu et al. (2010) \\
\hline
\end{tabular}

CAP chloramphenicol, CTC chlortetracycline, CIP ciprofloxacin, EFL enrofloxacin, LIN lincomycin, OFL ofloxacin, OTC oxytetracycline, $P E F$ pefloxacin, SMZ sulfamethazine, SDO sulfadoxine, SCP sulfachloropyridazine, $T C$ tetracycline, $T Y L$ tylosin

tamination of PV-OVPS may impact the productivity and quality of vegetables. Additionally, water contamination by antibiotics may affect protected vegetable production in hydroponics. Study results indicated that full nutrient solution spiked into milligrams per liter of antibiotics (e.g., CTC) inhibited growth vigor seriously (Cui et al. 2008). Vegetables are ready-to-eat freshly food crops, a kind of principal food. Uptake of antibiotics by vegetables contributes to human ingestion of antibiotics (Batt et al. 2006; Ye et al. 2007a, b), which may pose more serious health risks than other crops. Other major risks of introducing these substances into PVOVPS are the development of resistant pathogens and adverse impacts on soil beneficial microorganism that are closely correlated to vegetable health.

5.2 Antibiotic pollution of soil-vegetable systems, particularly PV-OVPS

Recently, contamination of antibiotics in soil-vegetable systems was given serious attention worldwide (Table 5) particularly in China (Shi et al. 2010; Hu et al. 2010). Antibiotic pollution in agro-ecosystems, particularly PVOVPS, is becoming an intractable environmental problem.

\subsubsection{Soil, groundwater pollution}

Zhao (2007) detected some kinds of antibiotics in all soils from vegetable fields in pig farm, common vegetable fields, nonpollution vegetable fields, and green vegetable fields in Pearl River Delta. Results showed that antibiotic levels in the soils of vegetable field in pig farm, common vegetable field, nonpollution vegetable field, and green vegetable fields presented a decrease trend. Shi et al. (2010) and $\mathrm{Hu}$ et al. (2010) firstly put forward the antibiotic pollution issues stemming from organic manures in PV-OVPS in China. $\mathrm{Hu}$ et al. (2010) firstly investigated the occurrence and seasonality of antibiotics in OVPS, including manure, soil, vegetables, and groundwater. Seasonality of concentration change of antibiotics in manure and groundwater ( $\mathrm{Hu}$ et al. 2010) were found, which depended on the application 
season of manure (Hamscher et al. 2000; Hu et al. 2010). Arable lands were applied in spring with a summer-high concentration, while organic bases were fertilized in winter with a winter-high concentration. Tai et al. (2010) found quinolone antibiotics in soils from vegetable field chronically fertilized with manure in subtropical area where high frequency are detected, decreasing with the increase of soil depth, and residual concentrations varied with the vegetable species. For long-term manure-amended soils planting vegetables, the soil contamination of antibiotics was significant ( $\mathrm{Li}$ et al. 2009b; Tai et al. 2010). Hu et al. (2010) detected nanograms per liter antibiotics in groundwater of OVPS. Li et al. (2011) has revealed an alarming condition of antibiotics in vegetable farmland soil of the Pearl River Delta, southern China. They found that the highest antibiotic concentrations were observed mainly in vegetable farmlands affiliated with livestock farms and the composition and concentration of antibiotics in soil were correlated with vegetable species. More importantly, chlortetracycline, sulfameter, and quinolones in some soils exceeded the ecotoxic effect trigger value $(100 \mu \mathrm{g} / \mathrm{kg})$ set by the Steering Committee of Veterinary International Committee on Harmonization (Li et al. 2011).

\subsubsection{Vegetable pollution by antibiotics}

Unintentional high-level introduction of antibiotics together with organic fertilizer are the fundamental inducement $(\mathrm{Li}$ et al. 2009a). Relevant scientists are trying to enrich the understanding to accumulation of antibiotics in vegetables, and the possible human health risks via food chain. Some results showed that vegetables could absorb, transport, and accumulate antibiotics in edible parts, such as lettuce (Boxall et al. 2006; Dolliver et al. 2007; Cui et al. 2008), potato (Dolliver et al. 2007), green onion (Kumar et al. 2005a), cabbage (Kumar et al. 2005a), carrot (Boxall et al. 2006), and leek (Wang and Han 2008). The distribution of antibiotics in vegetable organs was in the sequence leaf $>$ stem $>$ root $(\mathrm{Hu}$ et al. 2010), and the antibiotic levels in vegetable samples in winter were significantly higher than those in summer. Additionally, uptake of antibiotics by vegetables differed with antibiotic and vegetable species (Boxall et al. 2006). Overall, these works laid the sound foundation for understanding ecological risk of antibiotics and their potential adverse effects on human health by food chain.

\section{Research prospects}

6.1 Fates and ecological risks of antibiotics in agro-ecosystems: a global agro-ecological issue

Occurrence of antibiotics in animal excretions and environmental media, e.g., surface water, groundwater and soil, had been widely investigated and acknowledged. Furthermore, it has been widely accepted that antibiotics are emerging, broad-spectrum bioactive and persistent organic contaminants. Thus, it is inevitable to pollute the farmlands through repeated fertilization and irrigation. Accumulated antibiotics in agro-ecosystems may pose serious threat to soil ecosystem when soil accumulation occurs. Nowadays, many studies have been conducted to investigate the dynamics of antibiotics in agro-ecosystems, including soil persistence, soil adsorption, degradation, transport, and crop uptake (particularly vegetables), and a few valuable data have been presented. Some negative impacts of antibiotics on agro-ecosystems were preliminarily revealed, including (a) inhibition seed germination and crop growth, (b) inhibited microbial activity and soil enzymatic activity, (c) antibiotic accumulation in crop biomass, and (d) leaching and runoff diffusion into groundwater and groundwater. However, there are scarcity in-depth systematical investigations on some aspects, e.g., long-term effects of antibiotics on soil microorganisms, soil accumulation and crop absorption, and human health impacts. Furthermore, the environmental impacts of their metabolites of antibiotics have been little investigated, although they are considered to be bioactive. Thus, clarifying the migration processes, fates, and ecological impacts in agro-ecosystems is a key link to understand the environmental effects of antibiotics comprehensively. Monitoring and controlling of antimicrobial contaminants in arable lands and their crops will be of importance for preventing agro-ecosystems and consumers from damage.

\subsection{Fates and ecological risks of antibiotics in PV-OVPS:} the urgent agro-ecological issue

Vegetables, the indispensable staple produce providing humans with many beneficial substances, are readily contaminated by nitrate, heavy metals, pesticides (Liu et al. 2009b), and antibiotics during cultivation ( $\mathrm{Hu}$ et al. 2010). The contamination of antibiotics for protected vegetables and organic vegetables has become an urgent problem (Smukler et al. 2008; Siderer et al. 2005). The urgency of public damage of vegetable pollution is based on considerations below: (1) heavy acquirement and accumulation of harmful substance during short growth period, (2) high proportion of edible parts, and (3) short-term storage and fresh consumption. All these determine that there is larger quantity and quicker transportation of pollutants through vegetable than other plant food among food chains to human body. However, little is investigated about the occurrence, fate, and ecological impacts of antibiotics in PV-OVPS. Vegetables are main plant species cultivated in protected facilities in China. Different from PVPS, protected vegetable production systems are characterized by repeated fertilization and irrigation, elongated intensive cultivation period, strengthened environmental factors 
(high temperature, high humidity), and frequent disturbance of soil, which certainly affect the physicochemical and biochemical processes of antibiotics in soils. It is speculated that discharge amount of poultry and animal feces will reach 4.5 billion tons in China ( $\mathrm{Li}$ et al. 2009a). In China, near 80\% animal dejecta were utilized without comprehensive harmless disposal. Antibiotics are used in animal livestock production for therapeutic treatment of disease and at subtherapeutic levels for growth promotion and improvement of feed efficiency and their well-being (Boxall et al. 2003). Limited information regarding the fates and ecological impacts in protected and organic soil-vegetable systems was obtained, especially long-term monitoring data.

6.3 Strategies of lowering the introduction and ecological impacts of antibiotics in agro-ecosystems

\subsubsection{Controling the use of antibiotics as feed additives and human medicines to reduce excretion rate}

Currently, in order to minimize the occurrence of ecological problems and public health impacts caused by antibiotic contamination in agro-ecosystems, control methods of decreasing antibiotic commercial use, environmental release, and agro-input should be developed. First, the use of antibiotics in livestock farming should be reduced or limited compulsively to lower the agro-input from manures; second, relevant regulations with respect to human use of antibiotics should be issued to avoid the misuse in practices and over-release from biosolids and wastewater.

\subsubsection{Developing pretreatment technology to decrease the quantity of antibiotics in organic fertilizer and irrigation water}

Antibiotics-contained animal slurry or dejecta applied into farmlands as organic fertilizer without proper harmless pretreatments are the main source of antibiotics contribution to agro-ecosystems (Baguer et al. 2000). Anyway, to decrease the concentration of antibiotics in organic fertilizer and irrigation water is the first step to control the agro-input. Effective pretreatment methods, such as composting and anaerobic fermentation, wastewater treatment technology, must be further developed and optimized. In order to reduce the entrance of antibiotics by fertilization and irrigation ways, some standards of limits of antibiotics concentration in organic fertilizer and irrigation water need to be developed.

\subsubsection{Clarifying fates and rhizosphere dynamics of antibiotics in agro-ecosystems}

Several studies have been conducted to investigate the contamination status and impacts of antibiotics in protected soils on vegetable yield and quality (Zhao 2007; Wang and Han 2008; Li et al. 2008; Liu et al. 2009a) and organic agriculture (Hu et al. 2010). However, the behaviors of antibiotics between soil-root interfaces are little understood. In order to reduce the ecological risks, some biological mechanisms should be developed to accelerate the removal processes. Therefore, future extensive works should be focus on the investigations of fates and ecological risks of antibiotics in agro-ecosystems, particularly rhizosphere dynamics and the transfer from soil to crops.

\section{Concluding remarks}

Numerous studies dealing with antibiotic contamination of effluents of sewage treatment plants, surface water, groundwater, slurry or manures, soils, and sediments have been reported. Consequently, introduction of antibiotics into farmlands has given rise to a growing public concern over the ecological effects of antibiotics in agro-ecosystems. Besides deleterious effects on soil microflora and crop growth, antibiotics can provoke resistant pathogens through long-time exposure due to genetic variation and transfer. As novel persistent pollutants, antibiotics were included in limitations issued by the Food and Agriculture Organization (FAO) and the USA. However, there are no regulations involving antibiotics dealing with quality standards of produce in China. Although the acceptable daily intake values (less than $50 \mu \mathrm{g} / \mathrm{kg}$ ) and the maximum residue levels for animal tissues (below $1 \mathrm{mg} / \mathrm{kg}$ ) have been established (JECFA 2006) by FAO and the World Health Organization, limits have not been established for concentration of agricultural organic fertilizers and plant-based products, e.g., vegetables (Dolliver et al. 2007). Antibiotic ecotoxicological relevance is scarcely known and understood (Rooklidge 2004). Case-by-case studies in terms of species of antibiotics, plants, and soil use patterns are needed to investigate the ecotoxicological potential and their mechanisms of antibiotics in agro-ecosystems (Kotzerke et al. 2011), including source, exposure, and fate evaluation of soil antibiotics, impact investigations on plant and soil ecosystems, crop uptake, and transportation analysis via food chain in all kinds of agro-ecosystems. More importantly, some key issues should be revealed urgently, i.e., (1) crop rhizospheric impacts of antibiotics on soil microorganisms and relevant biochemical processes, particularly beneficial microorganisms (e.g., arbuscular mycorrhizal fungi, rhizobium etc.); (2) uptake of antibiotics via crop uptake, particularly leafy vegetables; (3) risk assessment of metabolites of antibiotics equivalent to their parental compounds in soil-crop systems for they usually being omitted in previous reports; (4) environmental assessment through leaching and runoff; 
and (5) fate and ecotoxicity of antibiotics in PV-OVPS. To sum up, further investigation is needed to fully understand the occurrence, fates in agro-ecosystems, particularly in PV-OVPS.

Acknowledgment This work was supported by the project of research and development program for China's sustainable agriculture (II), 2009-2014. I also want to thank three anonymous reviewers for their helpful comments and suggestions and Dr. Zhiping Zhu for providing some pictures.

\section{References}

Accinelli C, William C, Becker KJ, Michael M, Sadowsky J (2007) Environmental fate of two sulfonamide antimicrobial agents in soil. J Agric Food Chem 55(7):2677-2682

Alcock RE, Sweetman A, Jones KC (1999) Assessment of organic contaminant fate in wastewater treatment plants I. Selected compounds and physiochemical properties. Chemosphere 38:2247-2262

Arikan O (2008) Degradation and metabolization of chlortetracycline during the anaerobic digestion of manure from medicated calves. J Hazard Mater 158:485-490

Arikan O, Sikora LJ, Mulbry W, Khan SU, Rice C, Foster GD (2006) The fate and effect of oxytetracycline during the anaerobic digestion of manure from medicated calves. Process Biochem 41:1637-1643

Arikan O, Sikora LJ, Mulbry W, Khan SU, Foster GD (2007) Composting rapidly reduces levels of extractable oxytetracycline in manure from therapeutically treated beef calves. Bioresour Technol 98:169-176

Arikan O, Mulbry W, Ingram D, Millner P (2009a) Minimally managed composting of beef manure at the pilot scale: effect of manure pile construction on pile temperature profiles and on the fate of oxytetracycline and chlortetracycline. Bioresour Technol 100:4447-4453

Arikan O, Mulbry W, Rice C (2009b) Management of antibiotic residues from agricultural sources: use of composting to reduce chlortetracycline residues in beef manure from treated animals. J Hazard Mater 164:483-489

Aust MO, Godlinski F, Travis GR, Hao X, McAllister TA, Leinweber P (2008) Distribution of sulfamethazine, chlortetracycline and TYL in manure and soil of Canadian feedlots after subtherapeutic use in cattle. Environ Pollut 156:1243-1251

Baguer AJ, Jensen J, Krogh PH (2000) Effects of the antibiotics oxytetracycline and TYL on soil fauna. Chemosphere 40:751757

Bao YY, Zhou QX, Xie XJ (2008) Influence of tetracycline kind antibiotics on the control of wheat germination and root elongation. China Environ Sci 28(6):566-570

Bao Y, Zhou QX, Guan L, Wang Y (2009) Depletion of chlortetracycline during composting of aged and spiked manures. Water Manag 29:1416-1423

Bao YP, Li YW, Mo CH, Yao Y, Tai YP, Wu XL, Zhang Y (2010) Determination of six sulfonamide antibiotics in vegetables by solid phase extraction and high performance liquid chromatography. Environ Chem 29(3):513-518

Batchelder AR (1982) Chlortetracycline and oxytetracycline effects on plant growth and development in soil systems. J Environ Qual 11:675-678

Batt A, Kim S, Bruce IB, Aga DS (2006) Determination of antibiotics within various wastewater treatment plants and the impact of their discharges on surrounding surface waters. Abstr. ENVR 151. In ACS Natl. Meeting, 231st, Atlanta, GA. 26-30 Mar. 2006. Am. Chem. Soc., Washington, DC

Blackwell PA, Kay P, Boxall ABA (2007) The dissipation and transport of veterinary antibiotics in a sandy loam soil. Chemosphere 67:292-299

Bound JP, Voulvoulis N (2004) Pharmaceuticals in the aquatic environmental comparison of risk assessment strategies. Chemosphere 56:1143-1155

Bouwman GM, Reus JAWA (1994) Persistence of medicines in manure. Centre for Agriculture and Environment, CLM, 163,26

Boxall ABA (2004) The environmental side effects of medication: how are human and veterinary medicines in soils and water bodies affecting human and environmental health? EMBO Rep 5:1110-1116

Boxall ABA, Kolpin D, Halling-Sørensen B, Tolls J (2003) Are veterinary medicines causing environmental risks? Environ Sci Technol 37(15):286-294

Boxall ABA, Johnson P, Smith EJ, Sinclair CJ, Stutt E, Levy L (2006) Uptake of veterinary medicines from soils into plants. J Agric Food Chem 163(3):2288-2297

Bruce JR, Paul KSL, Michael M (2005) Emerging chemicals of concern: pharmaceuticals and personal care products (PPCPs) in Asia, particular reference to Southern China. Mar Pollut Bull 50:913-920

Burkhardt M, Stamm C, Waul C, Singer H, Muller S (2005) Surface runoff and transport of sulfonamide antibiotics and tracers on manured grassland. J Environ Qual 34:1363-1371

Cabello FC (2006) Heavy use of prophylactic antibiotics in aquaculture: a growing problem for human and animal health and for the environment. Environ Microbiol 8:1137-1144

Campagnac E, Sahraoui LA, Debiane D, Fontaine J, Laruelle F, Garcon G, Verdin A, Durand R, Shiralo P, Grandmougin F (2010) Arbuscular mycorrhiza partially protected chicory roots against oxidative stress induced by two fungicides, fenpropimorph and fenhexamid. Mycorrhiza 20:167-178

Campos JL, Garrido JM, Méndez R, Lema JM (2001) Effect of two broad-spectrum antibiotics on activity and stability of continuous nitrifying system. Appl Biochem Biotechnol 95(1):1-10

Castiglioni S, Bagnati R, Fanelli R, Pomati F, Calamari D, Zuccato E (2006) Removal of pharmaceuticals in sewage treatment plants in Italy. Environ Sci Technol 40:357-363

CEC (1998a) Council regulation 2788/98. Off J Eur Commun Legis L347:32

CEC (1998b) Council Regulation 2821/98. Off J Eur Commun Legis L351:4

Chen H, Dong YH, Wang H (2008) Residual characteristics of sulfanilamide in animal feces in Jiangsu Province. J AgroEnviron Sci 27(1):385-389

Christian T, Schneider RJ, Farber HA, Skutlarek D, Meyer MT, Goldbach HE (2003) Determination of antibiotic residues in manure, soil, and surface waters. Acta Hydrochim Hydrobiol 31:36-44

Cromwell GL, Davis G, Morrow W, Primo WEM, Rozeboom RA, Sims DW, Stanisiewski MD, Ho EP (1996) Efficacy of the antimicrobial compound U-82,127 as a growth promoter for growing-finishing pigs. J Anim Sci 74(6):1284-1287

Cui X, Qiao XL, Han CW, Wang Z (2008) Uptake of oxytetracycline and its phytotoxicity to lettuce. J Agro-Environ Sci 27(3):10381042

Diao XP, Sun YJ, Sun ZJ, Shen JZ (2004) Effects of Apramycin on microbial activity in different types of soil. Ecol Environ 13 (4):565-568

Díaz-Cruz MS, López de Alda MJ, Barcelo D (2003) Environmental behavior and analysis of veterinary and human drugs in soils, sediments and sludge. Trends Anal Chem 22(6):340-351 
Díaz-Cruz MS, de Alda MJL, Barcelo D (2006) Determination of antimicrobials in sludge from infiltration basins at two artificial recharge plants by pressurized liquid extraction-liquid chromatography-tandem mass spectrometry. J Chromatogr A 1130:7282

Ding C, He JZ (2010) Effect of antibiotics in the environment on microbial populations. Appl Microbiol Biotechnol 87:925-941

Dolliver H, Kumar K, Gupta S (2007) Sulfamethazine uptake by plants from manure-amended soil. J Environ Qual 36:1224-1230

Dolliver H, Gupta S, Noll S (2008) Antibiotic degradation during manure composting. J Environ Qual 37:1245-1253

EMEA (1994-2002) TYL summary report (Parts 1-5). Part 1: http:// www.emea.europa.eu/pdfs/vet/mrls/TYL1.pdf; Part 2: http:// www.emea.europa.eu/pdfs/vet/mrls/TYL2.pdf; Part 3: http:// www.emea.europa.eu/pdfs/vet/mrls/020597en.pdf; Part 4: http:// www.emea.europa.eu/pdfs/vet/mrls/073200en.pdf; Part 5: http:// www.emea.europa.eu/pdfs/vet/mrls/082902en.pdf

Farkas MH, Berry JO, Aga DS (2007) Chlortetracycline detoxification in maize via induction of glutathione $S$-transferases after antibiotic exposure. Environ Sci Technol 41:1450-1456

Focazio MJ, Kolpin DW, Barnes KK, Furlong ET, Meyer MT, Zaugg SD, Barber LB, Thurman ME (2008) A national reconnaissance for pharmaceuticals and other organic wastewater contaminants in the United States: II. Untreated drinking water resources. Sci Total Environ 402:201-216

Ge LK, Chen JW, Zhang SY, Cai XY, Wang Z, Wang CL (2010) Photodegradation of fluoroquinolone antibiotic gatifloxacin in aqueous solutions. Chin Sci Bull 55(15):1495-1500

Giger W, Alder AC, Golet EM, Kohler HPE, McArdell CS, Molnar E, Siegrist H, Suter MJF (2003) Occurrence and fate of antibiotics as trace contaminants in wastewaters sewage sludge and surface waters. Chimia 57:485-491

Göbel A, McArdell CS, Suter MJF, Giger W (2004) Trace determination of macrolide and sulfonamide antimicrobials a human sulfonamide metabolite and trimetoprim in wastewater using liquid chromatography coupled to electrospray tandem mass spectrometry. Anal Chem 76:4756-4764

Golet EM, Alder AC, Giger W (2002) Environmental exposure and risk assessment of fluoroquinolone antibacterial agents in wastewater and river water of the Glatt Valley Watershed, Switzerland. Environ Sci Technol 36:3645-3651

Gottlieb D (1976) The production and role of antibiotics in soil. J Antibiot 29:987-1000

Grote M, Schwake-Anduschus C, Michel R, Stevens H, Heyser W, Langenkämper G, Betsche T, Freitag M (2007) Incorporation of veterinary antibiotics into crops from manured soil. FAL Agric Res 57:25-32

Gulkowska A, He YH, So MK, Yeung LWY, Leung HW, Giesy JP, Lam PKS, Martin M, Richardson BJ (2007) The occurrence of selected antibiotics in Hong Kong coastal waters. Mar Pollut Bull 54(8):1287-1293

Halling-Sørensen B, Nors NS, Lanzky PF, Ingerslev F, Holten Lützhøft HC, Jørgensen SE (1998) Occurrence, fate and effects of pharmaceutical substances in the environment - a review. Chemosphere 36:357-393

Hamscher G, Abu-Quare A, Sczesny S, Hoper H, Nau H (2000) Determination of tetracyclines and TYL in soil and water samples from agricultural areas in Lower Saxony. In: van Ginkel LA, Ruiter A (eds) Proceedings of the Euroside IV Conference, National Institute of Public Health and the Environment (RIVM), Bilthoven, Netherlands, pp 522-526

Hamscher G, Sczesny S, Höper H, Nau H (2002) Determination of persistent tetracycline residues in soil fertilized with liquid manure by high performance liquid chromatography with electrospray ionization tandem mass spectrometry. Anal Chem $74: 1509-1518$
Hamscher G, Pawekzick HT, Sczesny S, Nau H, Hartung J (2003) Antibiotics in dust originating from a pig-fattening farm: a new source of health hazard for farmers? Environ Heal Perspect 111 (13):1590-1594

Hamscher G, Pawelzick HT, Hoper H, Nau H (2005) Different behavior of tetracyclines and sulfonamides in sandy soils after repeated fertilization with liquid manure. Environ Toxicol Chem 24:861-868

Heberer T (2002) Occurrence, fate, and removal of pharmaceutical residues in the aquatic environment: a review of recent research data. Toxicol Lett 131:5-17

Hirsch R, Ternes T, Haberer K, Kratz KL (1999) Occurrence of antibiotics in the aquatic environment. Sci Total Environ 225:109-118

Hu XG, Zhou QX, Xu L (2008) Determination of thirteen antibiotics residues in manure by solid phase extraction and high performance liquid chromatography. Chin J Anal Chem 36(9):11621166

Hu XG, Zhou QX, Luo Y (2010) Occurrence and source analysis of typical veterinary antibiotics in manure, soil, vegetables and groundwater from organic vegetable bases, northern China. Environ Pollut 158(9):2992-2998

JECFA (2006) Summary of evaluations performed by the JECFA (1956-2005) (1st through 65th meetings). Joint Food and Agriculture Organization of the United Nations and World Health Organization Expert Committee on Food Additives, Rome; WHO, Geneva, Switzerland

Jin CX, Chen QY, Sun RL, Zhou QX, Liu JJ (2009) Eco-toxic effects of sulfadiazine sodium, sulfamonomethoxine sodium and enrofloxacin on wheat, Chinese cabbage and tomato. Ecotoxicology 18:878-885

Jjemba PK (2002a) The effect of chloroquine, quinacrine, and metronidazole on both soybean plants and soil microbiota. Chemosphere 46:1019-1025

Jjemba PK (2002b) The potential impact of veterinary and human therapeutic agents in manure and biosolids on plants grown on arable land: a review. Agric Ecosyst Environ 93:267-278

Jongbloed AW, Lenis NP (1998) Environmental concerns about animal manure. J Anim Sci 76:2641-2648

Jørgensen SE, Halling-Sørensen B (2000) Drugs in the environment. Chemosphere 40:691-699

Kakimoto T, Osawa T, Funamizu N (2007) Antibiotic effect of amoxicillin on the feces composting process and reactivation of bacteria by intermittent feeding of feces. Bioresour Technol 98 (18):3555-3560

Katz SE (1980) The effects of human health. Subtherapeutic use of antimicrobials in animal feeds. National Academy of Sciences, Washington

Kay P, Blackwell PA, Boxall ABA (2005) Transport of veterinary antibiotics in overland flow following the application of slurry to arable land. Chemosphere 59:951-959

Kemper N (2008) Veterinary antibiotics in the aquatic and terrestrial environment. Ecol Indic 8:1-13

Khachatourians GG (1998) Agricultural use of antibiotics and the evolution and transfer of antibiotic-resistant bacteria. Can Med Assoc J 159:1129-1136

Khalvati M, Bartha B, Dupigny A, Schröder P (2010) Arbuscular mycorrhizal association is beneficial for growth and detoxification of xenobiotics of barley. J Soils Sediments 10:54-64

Kim SV, Carlson K (2005) LC-MS2 for quantifying trace amounts of pharmaceuticals compounds in soil and sediment matrices. Trends Anal Chem 24(7):635-644

Kim SC, Carlson K (2007) Temporal and spatial trends in the occurrence of human and veterinary antibiotics in aqueous and river sediment matrices. Environ Sci Technol 41:50-57

Kim S, Eichhorn P, Jensen JN, Scott WA, Aga DS (2005) Removal of antibiotics in wastewater: effect of hydraulic and solid retention 
times on the fate of tetracycline in the activated sludge process. Environ Sci Technol 39:5816-5823

Kim KR, Owens G, Kwon SI, So KH, Lee DB, Ok YS (2011) Occurrence and environmental fate of veterinary antibiotics in the terrestrial environment. Water Air Soil Pollut 214:163-174

Knapp CW, Dolfing J, Ehlert PAI, Graham DW (2010) Evidence of increasing antibiotic resistance gene abundances in archived soils since 1940. Environ Sci Technol 44:580-587

Kolpin DW, Furlong ET, Meyer MT, Thurman EM, Zaugg SD, Barber LB (2002) Pharmaceuticals, hormones, and other organic wastewater contaminants in U.S. streams, 1999-2000: a national reconnaissance. Environ Sci Technol 36:1202-1211

Kolz AC, Moorman TB, Ong SK, Scoggin KD, Douglass EA (2005) Degradation and metabolite production of TYL in anaerobic and aerobic swine manure lagoons. Water Environ Res 77:49-56

Kong WD, Zhu YG (2007) A review on ecotoxicology of veterinary pharmaceuticals to plants and soil microbes. Asian J Ecotoxicol 2 (1): $1-9$

Kong WD, Zhu YG, Fu BJ, Marschner P, He JZ (2006) The veterinary antibiotic oxytetracycline and $\mathrm{Cu}$ influence functional diversity of the soil microbial community. Environ Pollut 143:129-137

Kong WD, Zhu YG, Liang YC, Zhang J, Smith FA, Yang M (2007) Uptake of oxytetracycline and its phytotoxicity to alfalfa (Medicago sativa L.). Environ Pollut 147:187-193

Kotzerke A, Sharma S, Schauss K, Heuer H, Thiele-Bruhn S, Smalla K, Wilke BM, Schloter M (2008) Alterations in soil microbial activity and $N$-transformation processes due to sulfadiazine loads in pig manure. Environ Pollut 153(2):315-322

Kotzerke A, Fulle M, Sharma S, Kleineidam K, Welzl G, Lamshöft M, Schloter M, Wilke B (2011) Alterations in total microbial activity and nitrification rates in soil due to amoxicillin-spiked pig manure. J Plant Nutr Soil Sci 174(1):56-64

Kreuzig R, Höltge S (2005) Investigations on the fate of sulfadiazine in manured soil: laboratory experiments and test plot studies. Environ Toxicol Chem 24(4):771-776

Kulshrestha P, Giese RF, Aga DS (2004) Investigating the molecular interactions of oxytetracycline in clay and organic matter: insights on factors affecting its mobility in soil. Environ Sci Technol 38:4097-4105

Kumar K, Gupta SC, Chander Y, Singh AK (2005a) Antibiotic use in agriculture and their impact on terrestrial environment. Adv Agron 87:1-54

Kumar K, Gupta SC, Baidoo SK, Chander Y, Rosen CJ (2005b) Antibiotic uptake by plants from soil fertilized with animal manure. J Environ Qual 34:2082-2085

Kümmerer K (2001a) Drugs in the environment: emission of drugs, diagnostic aids and disinfectants into wastewater by hospitals in relation to other sources: a review. Chemosphere 45:957-969

Kümmerer K (2001b) Pharmaceuticals in the environment-source, fate, effects and risks. Springer, Berlin, p 265

Kurwadkar ST, Adams CD, Meyer MT, Kolpin DW (2007) Effects of sorbate speciation on sorption of selected sulfonamides in three loamy soils. J Agric Food Chem 55:1370-1376

Lancini G, Parenti F (1982) Antibiotics: an integrated view. Springer, New York, p 253

Li ZJ, Yao ZP, Zhang J, Liang YC (2008) A review on fate and ecological toxicity of veterinary antibiotics in soil environments. Asian J Ecotoxicol 3(1):15-20

Li ST, Liu RL, Shan H (2009a) Nutrient contents in main animal manures in China. J Agro-Environ Sci 28(1):179-184

Li YW, Mo CH, Zhao N, Tai YP, Bao YP, Wang JY, Li MY, Liang W (2009b) Investigation of sulfonamides and tetracyclines antibiotics in soils from various vegetable fields. Environ Sci 30 (6): $1762-1766$

Li YW, Wu XL, Mo CH, Tai YP, Huang XP, Xiang L (2011) Investigation of sulfonamide, tetracycline, and quinolone anti- biotics in vegetable farmland soil in the Pearl river delta area, southern China. J Agric Food Chem 59(13):7268-7276

Lindberg RH, Wennberg P, Johansson MI (2005) Screening of human antibiotic substances and determination of weekly mass flows in five sewage treatment plants in Sweden. Environ Sci Technol 39:3421-3429

Lindsey ME, Meyer TM, Thurman EM (2001) Analysis of trace levels of sulfonamide and tetracycline antimicrobials in groundwater and surface water using solid-phase extraction and liquid chromatography/mass spectrometry. Anal Chem 73:4640-4646

Liu F, Ying GG, Tao R, Zhao LL, Yang JF, Zhao LF (2009a) Effects of six selected antibiotics on plant growth and soil microbial and enzymatic activities. Environ Pollut 157:1636-1642

Liu WK, Yang QC, Du LF (2009b) Soilless cultivation for highquality vegetables with biogas manure in China: feasibility and benefit analysis. Renew Agric Food Syst 24(4):300-307

Luciana M, Salvatore C, Maurizio F (2003) Phytotoxicity to and uptake of enrofloxacin in crop plants. Chemosphere 52:12331244

Lumsden RD, Locke JR, Adkins ST, Walter JF, Rideout CJ (1992) Isolation and localization of the antibiotic gliotoxin produced by Gliocladium virens from alginate prill in soil and soilless media. Phytopathol 82:230-235

Managaki S, Murata A, Takada H, Tuyen BC, Chiem NH (2007) Distribution of macrolides, sulfonamides, and trimethoprim in tropical waters: ubiquitous occurrence of veterinary antibiotics in the Mekong Delta. Environ Sci Technol 41(23):8004-8010

Martinez-Carballo E, Gonzalez-Barreiro C, Scharf S, Gans O (2007) Environmental monitoring study of selected veterinary antibiotics in animal manure and soils in Austria. Environ Pollut 148 (2):570-579

McManus PS, Stockwell VO, Sundin GW, Jones AL (2002) Antibiotic use in plant agriculture. Annu Rev Phytopathol 40:443-465

Migliore L, Brambilla G, Cozzolino S, Gaudio L (1995) Effect on plants of sulphadimethoxine used in intensive farming (Panicum miliaceum, Pisum sativum, and Zea mays). Agric Ecosyst Environ 52:103-110

Migliore L, Brambilla G, Casoria P, Civitareale C, Cozzolino S, Gaudio L (1996) Effect of sulphadimethoxine contamination on barley (Hordeum distichum L., Poaceae, Liliposida). Agric Ecosyst Environ 60:121-128

Migliore L, Civitareale C, Brambilla G, Cozzolino S, Casoria P, Gaudio L (1997) Effects of sulphadimethoxine on cosmopolitan weeds (Amaranthus retroflexus L., Plantago major L. and Rumex acetosella L.). Agric Ecosyst Environ 65:163-168

Migliore L, Civitareale C, Cozzolino S, Casoria P, Brambilla G, Gaudio L (1998) Laboratory models to evaluate phytotoxicity of sulphadimethoxine on terrestrial plants. Chemosphere 37:29572961

Migliore L, Cozzolino S, Fiori M (2003) Phytotoxicity to and uptake of enrofloxacin in crop plants. Chemosphere 52:1233-1244

Mohring SI, Strzysch I, Fernandes MR (2009) Degradation and elimination of various sulfonamides during anaerobic fermentation: a promising step on the way to sustainable pharmacy? Environ Sci Technol 43:2569-2574

Montforts MH (1999) Environmental risk assessment for veterinary medicinal products. Part 1: Other than GMO containing and immunological products. RIVM report 601300001, N120. National Institute of Public Health and the Environment, Bilthoven

Morris AK, Masterton RG (2002) Antibiotic resistance surveillance: action for international studies. J Antimicrob Chemother 49(1):710

Pedrouzo M, Borrull F, Pocurull E, Marcé RM (2011) Presence of pharmaceuticals and hormones in waters from sewage treatment plants. Water Air Soil Pollut 217(1-4):267-281 
Pena A, Paulo M, Silva LJG, Seifrtova M, Lino CM, Solich P (2010) Tetracycline antibiotics in hospital and municipal wastewaters: a pilot study in Portugal. Anal Bioanal Chem 396:2929-2936

Phillips I, Casewell M, Cox T, Groot BI, Friis C, Jones R, Nightingale G, Preston R, Waddell J (2004) Does the use of antibiotics in food animals pose a risk to human health? A critical review of published data. J Antimicrob Chemother 53:28-52

Poels JP, Assche V, Verstraete W (1984) Effects of disinfectants and antibiotics on the anaerobic digestion of piggery waste. Agric Wastes 9(4):239-247

Rabølle M, Spliid NH (2000) Sorption and mobility of metronidazole, olaquindox, oxytetracycline and tylosin in soil. Chemosphere 40 (7):715-722

Renew JE, Huang CH (2004) Simultaneous determination of fluoroquinolone, sulfonamide and trimethoprim antibiotics in wastewater using tandem solid-phase extraction and liquid chromatography electrospray-mass spectrometry. J Chromatogr A $1042: 113-121$

Rooklidge SJ (2004) Environmental antimicrobial contamination from terraccumulation and diffuse pollution pathways. Sci Total Environ 325(1-3):1-13

Sacher F, Lange FT, Brauch HJ, Blankenhorn I (2001) Pharmaceuticals in groundwaters: analytical methods and results of a monitoring program in Baden-Würtemberg, Germany. J Chromatogr A 938:99-210

Sarmah AK, Meyer MT, Boxall ABA (2006) A global perspective on the use, sales, exposure pathways, occurrence, fate and effects of veterinary antibiotics (VAs) in the environment. Chemosphere 65 (5): 725-759

Sassman SA, Lee LS (2005) Sorption of three tetracyclines by several soils: role of $\mathrm{pH}$ and cation exchange. Environ Sci Technol 39:7452-7459

Sassman AS, Sarmah AK, Lee LS (2007) Sorption of tylosin A D, and tylsoin A-Aldol and degradation of tylosin A in soils. Environ Toxicol \& Chem 26:1629-1635

Schlüsener MP, Bester K (2006) Persistence of antibiotics such as macrolides, tiamulin and salinomycin in soil. Environ Pollut 143:565-571

Shanahan P, Borro A, ÓGara F, Glennon JD (1992) Isolation, trace enrichment and liquid chromatographic analysis of diacetylpholoroglucinol in culture and soil samples using UV and amperometric detection. J Chromatogr A 606:171-177

Shi Y, Zhao MQ, Wang J, Song YF (2010) Effect of antibiotics from organic manure on protected vegetable soil-plant system: a review. J Agro-Environ Sci 29(supl):240-244

Siderer Y, Maquet A, Anklam E (2005) Need for research to support consumer confidence in the growing organic food market. Trends Food Sci Technol 16:332-343

Smith DL, Harris AD, Johnson JA, Silbergeld EK, Morris JG Jr (2002) Animal antibiotic use has an early but important impact on the emergence of antibiotic resistance in human commensal bacteria. Proc Nat Acad Sci U S A 99:6434-6439

Smukler SM, Jackson LE, Murphree L, Yokota R, Koike ST, Smith RF (2008) Transition to large-scale organic vegetable production in the Salinas Valley, California. Agric Ecosyst Environ 126:168188

Snow DD, Bartelt-Hunty SL, Saunders SE, Devivo SL, Cassada DA (2009) Detection, occurrence, and fate of emerging contaminants in agricultural environments. Water Environ Res 81(10):941-958

Stolker AMM, Niesing W, Hogendoorn EA, Versteegh JFM, Fuchs R, Brinkman UAT (2004) Liquid chromatography with triplequadrupole or quadrupole-time of flight mass spectrometry for screening and confirmation of residues of pharmaceuticals in water. Anal Bioanal Chem 378:955-963

Stone JJ, Clay SA, Zhu ZW, Wong KL, Porath LR, Spellman GM (2009) Effect of antimicrobial compounds TYL and chlortetra- cycline during batch anaerobic swine manure digestion. Water Res 43:4740-4750

Stoob K, Singer HP, Mueller SR, Schwarzenbach RP, Stamm CH (2007) Dissipation and transport of veterinary sulfonamide antibiotics after manure application to grassland in a small catchment. Environ Sci Technol 41(21):7349-7355

Summer ME (2000) Beneficial use of effluents, wastes, and biosolids. Commun Soil Sci Plant Anal 31:1701-1715

Tai YP, Mo CH, Li YW, Wu XL, Zou X, Gao P, Huang XD (2010) Concentration and distribution of quinolone antibiotics in longterm manure-amended soils. China Environ Sci 30(6):816-821

Tamtam F, Mercierb F, Le Botb B, Eurinc J, Tuc DQ, Clémentb M, Chevreuilc M (2008) Occurrence and fate of antibiotics in the Seine River in various hydrological conditions. Sci Total Environ 393:84-95

Ternes TA (1998) Occurrence of drugs in German sewage treatment plants and rivers. Water Res 32:3245-3260

Thiele-Bruhn S (2003) Pharmaceutical antibiotic compounds in soils: a review. J Plant Nutr Soil Sci 166:45-167

Thiele-Bruhn S, Beck IC (2005) Effects of sulfonamide and tetracycline antibiotics on soil microbial activity and microbial biomass. Chemosphere 59:457-465

Thiele-Bruhn S, Peters D (2007) Photodegradation of pharmaceutical antibiotics on slurry and soil surfaces. Landbauforschung Völkenrode 57:13-23

Thomashow LS, Weller DM (1995) Current concepts in the use of introduced bacteria for biological disease control: mechanisms and antifungal metabolites. In: Stacey G, Keen N (eds) Plantmicrobe interactions, vol 1. Chapman \& Hall, New York, pp $187-235$

Thomashow LS, Bonsall RF, Weller DM (1997) Antibiotic production by soil and rhizosphere microbes in situ. In: Hurst CJ, Knudson GR, Mclnerney MJ, Stetzenbach LD, Walter MV (eds) Manual of environmental microbiology. ASM Press, Washington, pp 493-499

Tolls J (2001) Sorption of veterinary pharmaceuticals in soils: a review. Environ Sci Technol 35:3397-3406

Topp W (1981) Biologie der Bodenorganismen. Quelle \& Meier-UTB, Heidelberg, p p224

UCS(Union of Concerned Scientist). Hogging it!: estimates of antimicrobial abuse in livestock. 2001. p.4 http://www.ucsusa. org/food and environment/antibiotic resistance/indexN

Vieno N, Tuhkanen T, Kronberg L (2006) Analysis of neutral and basic pharmaceuticals in sewage treatment plants and in recipient rivers using solid phase extraction and liquid chromatographytandem mass spectrometry detection. J Chromatogr A 1134:101111

Wang J, Han JZ (2008) Effects of heavy metals and antibiotics on soil and vegetables. J Ecol Rural Environ 24(4):90-93

Wang M, Tang JC (2010) Research of antibiotics pollution in soil environments and its ecological toxicity. J Agro-Environ Sci 29 (supl):261-266

Wang R, Liu TZ, Wang $\mathrm{T}$ (2006) The fate of antibiotics in environment and its ecotoxicology: a review. Acta Ecologica Sinica 26(1):265-270

Wang B, Sun C, Hu GJ (2007) Advances in the potential risks of antibiotics in environment. Environ Sci Technol 30(3):108-111

Watanabe N, Bergamaschi BA, Loftin KA, Meyer MT, Harter T (2010) Use and environmental occurrence of antibiotics in freestall dairy farms with manured forage fields. Environ Sci Technol 44:6591-6600

Watts CD, Crathorne B, Fielding M, Killops SD (1982) Nonvolatile organic compounds in treated waters. Environ Heal Perspect 46:87-89

Wegener HC (1999) The consequences for food safety of the use of fluoroquinolones in food animals. New Eng J Med 340:15811582 
Wehrhan A, Kasteel R, Simunek J, Groeneweg J, Vereecken H (2007) Transport of sulfadiazine in soil columns - experiments and modelling approaches. J Contam Hydrol 89(1-2):107-135

Wei X, Wu SC, Nie XP, Yediler A, Wong MH (2009) The effects of residual tetracycline on soil enzymatic activities and plant growth. J Environ Sci Health Part B 44:461-471

Willer H, Lilcher L (eds.) The world of organic agriculture-statistics and emerging trends 2010. International Federation of Organic Agriculture Movements (IFOAM). Boon and FiBL Frick

Winckler C, Grafe A (2001) Use of veterinary drugs in intensive animal production: evidence for persistence of tetracycline in pig slurry. J Soils Sediments 1:66-70

Winding A, Hund-Rinke K, Rutgers M (2005) The use of microorganisms in ecological soil classification and assessment concepts. Ecotoxicol Environ Saf 62:230-248

Witte W (1998) Medical consequences of antibiotic use in agriculture. Science 279:996-997

Wu CX, Spongberg AL, Witter JD, Fang M, Czajkowski KP (2010a) Uptake of pharmaceutical and personal care products by soybean plants from soils applied with biosolids and irrigated with contaminated water. Environ Sci Technol 44(16):6157-6161

Wu QF, Hong HL, Li ZH (2010b) Progress of research on antibiotic contamination. Safety Environ Eng 17(2):68-72

Xiao QM, Yang YH (1997) Analyzing soil fertility of protected lands of Liaoning province. Liaoning Agric Sci 3:17-21

Xie XY, Zhang YQ, Li ZJ, Liang YC, Yao JH, Zhang SQ (2009) Cultivar differences in toxic effects of oxytetracycline on wheat (Triticum durum). Asian J Ecotoxicol 4(4):577-583

Xu WH, Zhang G, Zou SC (2007a) Determination of selected antibiotics in the Victoria Harbour and the Pearl River, South China using highperformance liquid chromatography-electrospray ionization tandem mass spectrometry. Environ Pollut 145:672-679

Xu WH, Zhang G, Li XD, Zou SC, Li P, Hu ZH (2007b) Occurrence and elimination of antibiotics at four sewage treatment plants in the Pearl River Delta (PRD), South China. Water Res 41:4526-4534

Yang YD, Chen DH, Huang MH (2010a) The source of antibiotics in the environment and progress of its ecological impact research. Environ Sci Manag 35(1):140-143

Yang JF, Ying GG, Zhao JL, Tao R, Su HC, Chen F (2010b) Simultaneous determination of four classes of antibiotics in sediments of the Pearl Rivers using RRLC-MS/MS. Sci Total Environ 408:3424-3432

Yao H, He Z, Wilson MJ, Campbell CD (2000) Microbial biomass and community structure in a sequence of soils with increasing fertility and changing land use. Microb Ecol 40:223-237

Yao LX, Li GL, Dang Z (2006) Major chemical components of poultry and livestock manures under intensive breeding. Chin J Appl Ecol 17(10):1989-1992

Yao JH, Niu DK, Li ZJ, Liang YC, Zhang SQ (2010) Effects of antibiotics oxytetracycline on soil enzyme activities and micro- bial biomass in wheat rhizosphere. Scientia Agricultura Sinica 43 (4):721-728

Ye S, Yao ZW, Na GS, Wang JY, Ma DY (2007a) Rapid simultaneous determination of 14 sulfonamides in wastewater by liquid chromatography tandem mass spectrometry. J Sep Sci 30:2360 2369

Ye Z, Weinberg HS, Meyer MT (2007b) Trace analysis of trimethoprim and sulfonamide, macrolide, quinolone, and tetracycline antibiotics in chlorinated drinking water using liquid chromatography electrospray tandem mass spectrometry. Anal Chem 79:1135-1144

Zhang FS (2008) Report on the strategies for fertilizer industry and scientific fertilization in China. China Agricultural University Press, Beijing, pp 5-53

Zhang T, Li B (2011) Occurrence, transformation, and fate of antibiotics in municipal wastewater treatment plants. Crit Rev Environ Sci Technol 41(11):951-998

Zhang JQ, Dong YH, An Q, Liu XC (2005a) Environmental fate of veterinary medicines in soil. Soils 37(4):353-361

Zhang YC, Li QY, Zhai CX (2005b) Analysis and assessment of fertilization status in greenhouse of Hebei. Hebei Agric Sci 9 (3):61-67

Zhang H, Luo Y, Zhou QX (2008a) Research advancement of ecotoxicity of tetracycline antibiotics. J Agro-Environ Sci 27 (2):407-413

Zhang HM, Zhang MK, Gu GP (2008b) Residues of tetracyclines in livestock and poutry manures and agricultural soils from North Zhejing provinces. J Ecol Rural Environ 24 (3):69-73

Zhang MK, Wang LP, Zhang SA (2008c) Adsorption and transport characteristics of two exterior two source antibiotics in some agricultural soils. Acta Ecologica Sinica 28(2):761-766

Zhao N (2007) Status of soil antibiotic pollution from typical vegetable fields in Pearl River Delta. Master thesis of Jinan University, Guangzhou

Zhao FY, Chen CL (2001) Effects of nitrogen rate on yield and quality of vegetables. Syst Sci Compr Stud Agric 17(1):43-44

Zhao L, Dong YH, Wang H (2010) Residues of veterinary antibiotics in manures from feedlot livestock in eight provinces of China. Sci Total Environ 408:1069-1075

Zhou QX, Luo Y, Wang ME (2007) Environmental residues and ecotoxicity of antibiotics and rheir resistance gene pollution: a review. Asian J Ecotoxicol 2(3):243-251

Zhu CX, Song Y (2006) Discussion on the situation and development of agro-antibiotic in China. Rev China Agric Sci Technol 8(6):17-19

Zielezny Y, Groeneweg J, Vereecken H, Tappe W (2006) Impact of sulfadiazine and chlortetracycline on soil bacterial community structure and respiratory activity. Soil Biol Biochem 38:2372-2380

Zuccato E, Calamari D, Natangelo M, Fanelli R (2000) Presence of therapeutic drugs in the environment. Lancet 355:1789-1790 